\title{
Identical Twins, Different Wombs: A Literature Review on Attiba:q in Arabic and Antonymy in English
}

\author{
https://doi.org/10.33806/ijaes2000.20.2.1 \\ Hamada Hassanein \\ Prince Sattam bin Abdulaziz University, Saudi Arabia \\ Mansoura University, Egypt
}

\begin{abstract}
The current overview article seeks to diachronically compare the development of Arabic tiba:q and English 'antonymy' in the long run of literature and to track and review the theoretical and practical advancements of both phenomena in comparative contexts. The objective is twofold: (a) to comparatively identify points of similarity between the two phenomena in theory and $(b)$ to comparatively identify points of dissimilarity between the two phenomena in practice. To do so, a comparative diagnostic approach is adopted. The study concludes that (1) both phenomena share several aspects in theory and practice, (2) they prove rather difficult to be defined operationally as the existing definitions overlap and denote a multiplicity of semantically versatile concepts, underpinning a case of polyonymy in reference to both notions, (3) the two phenomena are dichotomously approached: canonically vs. noncanonically, lexically vs. semantically, literally vs. nonliterally and textually vs. contextually, and (4) classifying both phenomena is triggered by the theoretical insights and practices of the classifiers; traditional classification is form-based and a context-free relation holds between opposites whereas more recent classification depends on syntax and a context-dependent relation holds between opposites. The scope of the two phenomena is currently widened to feature opposition between antonyms, contrasts, counterparts, incompatibles, analogs, and the like. Therefore, the study recommends further extensive research on the non-canonicity of both phenomena.
\end{abstract}

Keywords: antonymy, Arabic, attiba:q, diachrony, English

\section{Introduction}

Humans are said to share a general tendency towards organizing their thoughts into binary lexical-semantic oppositions (Lyons 1977). The central aspect of lexical-semantic opposition is technically dubbed attiba: $q$ in Arabic and antonymy in English. In Arabic, attiba: $q$ appears to be the prototype of all lexicalsemantic relations and seems to permeate almost all types of discourse. The motivation for the extensive use of attiba: $q$ in spoken and written discourses (talks and texts) resides in its patent potential for emphasizing and demonstrating meaning. Therefore, attiba: $q$ is omnipresent and looms large across Classical, Modern Standard and Vernacular Arabic genres, as in Al-Qur?a:n, Al-Hadi:th, prose, poetry, and everyday speech. In English, antonymy is believed to be the "most readily apprehended" (Cruse 1986:197) and the "archetypal lexical semantic relation" (Murphy 2003:169). It is massively pervasive and its scope is 
much greater than that of its fellow relations with which it is often grouped, such as synonymy, hyponymy, and meronymy (Jones 2002). Echoing earlier rhetorical observations about the importance of antonymy, Cruse (1986:197) quotes philosophers and others as noting a tendency of things to slip into opposite states. Attiba:q, antonymy, or whatever name it has across languages, is "a fundamental experience-organising mechanism" (Jones 2002:3).

Previous research on attiba: $q$ in Arabic is extremely sparse and leaves a significant gap between theory and practice in Arabic literature. Few studies were conducted on this notion, drawing on theoretically and methodologically different approaches. ${ }^{c}$ Afi:fi: (1998) studied the rhetorical aspects of attiba:q in Al-Hadi:th from a formal perspective and tested a representative sample thereof against the static and absolute categories he pieced together from Arabic sources on ${ }^{c} \mathrm{ilm}$ albala:gha 'rhetorics' and 'ilm al-badi:c 'tropology'. Al-Jamma:s (2002) investigated attiba: $q$ in Al-Qur?a:n from a rhetorical perspective and applied the pieced-together categories to a considerable sampling therefrom. Both studies used the same formal typology which was applied to different but relevant genres. Building on a rigorous and retrievable typology of English antonymy by Jones (2002), Hassanein (2013) developed a canonical approach to Qur'anic tiba:q, identifying and classifying its discourse functions and frames. Drawing on Jones (2002), Davies (2012, 2013) and Hassanein (2013), Hassanein (2018) conflated their typologies and developed a combinatory classification, applying it to a representative dataset from Al-Hadi:th canon in quantitative and qualitative terms.

In contrast, previous literature on antonymy in English is extensive and has approximately bridged the gaps between the theoretical and the empirical approaches. Cruse $(1976,1986)$ and Lyons $(1977,1995)$ investigated antonymy as a paradigmatic relation, and each introduced his own formal classification of it. Both of their classifications are syntax-free, context-free, and form-based. The classes and subclasses developed depend in essence on the theoretical and empirical insights of the classifier, thus giving rise to a conceptual overlapping of antonyms, opposites, and contrasts. Gorgis and Al-Halawachy (2001) undertook a riveting review of western views on antonymy and other terms related to it, such as oppositeness, opposition, contrast, and incompatibility, locating antonymy under the last as an umbrella term. They also classified types of oppositeness based on Cruse's context-free and syntax-independent approach which is the most adequate for them.

Aspects of lexical-semantic opposition in English have remained under the lens of syntax- and context-free paradigmatic approach until Mettinger (1994), Jones (2002), and Davies $(2012,2013)$ approached such aspects afresh from a context-dependent syntagmatic perspective, conducting a more structural analysis than those of Justeson and Katz (1991) and Fellbaum (1995). The syntagmatic approach has championed the co-occurrence hypothesis since its inception and a multiplicity of typologies have emerged in this regard. Mettinger (1994) logged nine syntactic frames of canonical opposition. Jones (2002) quantified and typified eight discourse functions of canonical antonymy. Davies $(2012,2013)$ qualified and exemplified another eight of noncanonical opposition. Of these three 
typologies, Jones's is the most retrievable and the most replicable, being the standard toolkit for analyzing antonyms across languages, including Swedish (Murphy et al. 2009), Japanese (Muehleisen and Isono 2009), Dutch (Lobanova et al. 2010), Serbian (Kostić 2011), Romanian (Gheltofan 2013), Arabic (Hassanein 2013, 2018; AlHedayani 2016), and Chinese (Hsu 2015).

This study seeks to undertake a comparative review of aspects of lexicalsemantic opposition: attiba:q and al-muqa:bala in Arabic and 'antonymy' and 'opposition' in English. ${ }^{1}$ It aims to theoretically and empirically survey the development of these two interdependent aspects since their inception in the literature. Specific objectives are (a) to compare how the two aspects diachronically developed in theory and (b) to compare how these two aspects diachronically developed in practice. Typologies and typical cases from both languages will also be reviewed and future developments will be foreshadowed. To achieve these objectives, three questions are necessarily posed:

1. Are the two aspects theoretically similar or different across Arabic and English?

2. Are they empirically similar or distinct?

3. Are they typologically similar or distinct?

\section{Perspectives}

Aspects of lexical-semantic opposition in Arabic include a triad of lexicalsemantic relations: attiba:q, al-muqa:bala and attada:dd. Attiba:q 'antonymy' has both lexical and semantic definitions (cf. Fari:d 2000; Al-Qarta:janni: 2008). It is labelled rhetorically differently, sometimes as al-muqa:bala 'antithesis' (Bussmann 1996) or 'opposition' (Davies 2012), attada:dd 'autoantonymy' (AlKharabsheh 2008) or 'contronymy' (Karaman 2008), and attaka:fu? 'parallelism' (Quda:ma Ibn Ja ${ }^{\mathrm{c}}$ far N.D.). However, rhetoricians are unanimous about defining it as 'bringing two lexical or semantic opposites together' (cf. Al- ${ }^{\mathrm{C}} \mathrm{Alawī} 1914$; AlQayrawa:ni: 1943; Al- ${ }^{\mathrm{C} A s k a r i: ~ 1952 ; ~ A l-Q a r t a: j a n n i: ~ 2008 ; ~ A l-B a q i l l a: n i: ~ 1972 ; ~}$ Ibn Al-Mu'taz 1982; Assakka:ki: 1987; Sibawayh 1988; Attabri:zi: 1994; Tha ${ }^{c}$ lab 1995; Al-Jurja:ni: N.D.; Azzarkashi: 2006; 'Ati:q N.D.).

These definitions show that the term is lexicalized differently but features the same semantic concept. It is considered by specialists to be only semantic, lexical, or both and occurs at word or above word level between the same or different parts of speech. A distinction has always been drawn between attiba:q and al-muqa:bala, whereby the former holds between single opposites (one-toone); the latter between multiple opposites (many-to-many). The former occurs only between opposite words, as in $t a^{c} m a: / l a$ : $t a^{c} m a$ : 'blind/not blind'; the latter between opposites or non-opposites, as in al-qulu:b/al-?absa:r 'hearts/eyes' (cf. Ibn Al-Qayyim 1327 H.; Husayn 1983; Bin Ma:lik 1989; Ashshaykh 1999). Attada:d is another semantic phenomenon in which a single item referred to as didd 'contronym' carries two opposite senses, as in jalal meaning both saghi:r/kabi:r 'little/big' (cf. al-Kharabsheh 2008).

Aspects of lexical-semantic opposition in English are also tripartite in nature, including a triad of opposite relations: antonymy, opposition (contrast) and contronymy (autoantonymy). Murphy and Andrew (1993:302) establish that 
antonymy represents an intriguing relation difficult to specify formally. "The word 'antonymy' (Grk antí- 'against,' ónyma (=ónoma) 'name') was coined in 1867 by C. J. Smith as an opposite of 'synonymy' and since 1867 numerous attempts have been made to pin down the meaning of antonymy and formulate a workable definition of the term" (Jones 2002:9). Antonymy is considered to be a subclass of opposites referred to as gradables (Cruse 1976, 1986; Murphy and Andrew 1993; Lyons 1995; Bussmann 1996) and binaries (Murphy 2003; Cruse 2006; Hurford et al. 2007). It is considered lexical in nature (e.g., Cruse 1976, 1986; Lyons 1977, 1995; Murphy and Andrew 1993; Bussmann 1996), semantic in nature (e.g., Fromkin et al. 2003; Crystal 2008) or both (e.g., Jones 2002; Murphy 2003). Antonymy is sometimes seen in the broadest sense as including all types of lexical and semantic oppositions (e.g., Lehrer and Lehrer 1982; Crystal 2008) and sometimes as being opposite of synonymy (e.g., Finch 1998). Fellbaum (1995) points out that antonymy occurs not merely between pairs within the same word class, but also across word class, as in 'loving/hate', 'love/hates', 'loved/hatred', as well as between grammatically compatible pairs, such as 'loves/hates' and 'loved/hated' (cited in Jones 2002:11). A technical term, which is distinguished from 'antonymy' and which Murphy (2003) calls 'contrast', is 'opposition' (cf. Davies 2012, 2013). It is used as an umbrella term for all different guises of contrasts, (non)canonical and (con)textual, lexical and semantic (broadly, conceptual).

It is worth noting that contronymy or autoantonymy is not institutionalized or well researched as the other aspects in English academia. Contronymy occurs when a minimum of two senses of a lexical unit contrast each other semantically (Karaman 2008:173).

\section{Approaches}

\subsection{Approaches to attiba:q}

Review of the literature on attiba:q in Arabic rhetoric and semantics unravels different, albeit complementary, scholarly approaches to the phenomenon. In general, the phenomenon is methodologically and analytically dissected according to dyadic approaches: lafTHi: vs. macnawi: 'lexical vs. semantic' and mahd vs. ghayr mahd 'canonical vs. non-canonical'.

\subsubsection{LafTHi: vs. macnawi:}

Some Arabic rhetoricians and semanticists approached attiba: $q$ based on lexical criteria. They consider it only lafTHi: in nature and view it as a lexical relation specific only to words. Al-Qazwi:ni: (2003:255), for example, adopted a lexical approach to attiba: $q$ and classified it according to word class. Some other rhetoricians and semanticists approached attiba: $q$ according to semantic criteria and consider it just $m a^{c}$ nawi: in nature and specific to oppositeness of meanings. For instance, Attabri:zi: (1994:170) is explicit on semantic tiba: $q$ which brings two opposite senses together in discourse. Al-Jurja:ni: (N.D.:20) prioritizes semantic antonymy over lexical antonymy and confines its configurations to single lexemes with single opposite meanings. Al-Qarta:janni: (2008:43) assigns priority to semantic tiba:q which he calls al-muta:baqa al-mahda 'canonical antonymy'. 
The lexical approach or the semantic approach is not solely enough to comprehensively cover the range of attiba: $q$ in Arabic. Opposition in Arabic figures not only between lexemes but also between meanings and concepts at and above word level. Both approaches must be complementary and hang together to accurately diagnose the case of attiba: $q$ in Arabic. Therefore, the great majority of Arabic rhetoricians and semanticists are unanimous that attiba: $q$ is a lexicalsemantic phenomenon in which opposite lexemes and meanings are paired in discourse (texts and talks). Sibawayh (1988:24) considers lexical tiba: $q$ and semantic tiba:q as interrelated and pinpoints that lexemes become opposites as their meanings are opposite, such as qa:ma/jalasa 'stand/sit'. Al- ${ }^{\mathrm{c}}$ Alawi: (1914:377) includes attiba:q under al-muqa:bala and describes lexical tiba:q as the opposition of a lexeme to another and semantic tiba: $q$ as the opposition of one lexeme to another based on semantic, not lexical, criteria. In his divisions of attiba:q, Al-Madani: (1968:33) points out that it is lexical and semantic in that either two words or two meanings are brought together into opposition.

\subsubsection{Mahd vs. ghayr mahd}

Another interesting debate among Arabic rhetoricians and semanticists revolves around the question whether attiba:q is mahd 'canonical' or ghary mahd 'noncanonical'. The literature review reveals the positioning of attiba: $q$ on a gradable cline from canonicity to non-canonicity. Attabri:zi: (1994:170) draws a distinction between addidd 'antonym' and ma: yaqu:mu maqa:ma addidd 'what replaces the antonym' in allusion to attiba:q al-mahd 'canonical antonymy' and attiba:q ghayr al-mahd 'non-canonical antonymy'. Al-Pamidi (1992:288) also makes a distinction between addidd 'antonym' and ma: yuqa:rib addidd 'near-antonym' in allusion to canonical tiba: $q$ and semi-canonical tiba:q, a distinction shared by AlKhafa:ji: (1982:199). Quda:ma Ibn Ja ${ }^{c}$ far (N.D.:141) makes an explicit reference to all aspects of attiba:q, dubbing them attaqa:bul 'opposition' in its (non-) canonical guises. ${ }^{\mathrm{c}} \mathrm{Abd} \mathrm{Al-}{ }^{\mathrm{c}} \mathrm{Azi}: \mathrm{z}$ Al-Jurja:ni: (1966:44) mentions that the most common type of attiba:q is that in which macnaya:n ghayr mutaqa:bila:n 'two non-canonical meanings' are expressed by lafTHayn mutaqa:bilayn 'canonical opposites'. Ibn Al-Pathi:r (N.D.:144) explicitly refers to the pairing of one lexeme with diddih 'canonical antonym' and ma laysa bi-diddih 'non-canonical antonym'. Al-Qarța:janni: (2008:48) differentiates al-muta:baqa al-mahda 'canonical antonymy' from al-muta:baqa ghayr al-mahda 'non-canonical antonymy'. He subsumes two subcategories under the latter category: putting a lexeme in opposition to ma: yatanazzal minhu manzilata addidd 'semi-canonical antonym' and to ma: yukha:lifuh 'non-canonical antonym'. Al- ${ }^{\mathrm{c}}$ Alawi: (1914:378) broadens the scope of attiba:q by preferring to call it al-muqa:bala and categorizing its manifestations into four categories:

1. opposing a lexeme with its lexical antonym,

2. opposing a lexeme with its semantic antonym,

3. opposing a lexeme with its lexical contrast, and

4. opposing a lexeme with its lexical analog.

Categories (1) and (2) typify canonical antonymy; category (3) semi-canonical antonymy; and category (4) non-canonical opposition. 


\subsection{Approaches to antonymy}

A literature review of antonymy in English semantics mirrors its counterpart in Arabic rhetoric and demonstrates similar dyadic approaches to it: lexical vs. semantic, canonical vs. non-canonical and syntax-free vs. syntax-dependent.

\subsubsection{Lexical approach vs. semantic approach}

Jones (2002) points out that, generally, there have been two distinct ways of defining antonymy in English: one is based on lexical criteria; the other one is on semantic criteria. Exponents of the lexical approach mainly include Justeson and Katz (1991) who view antonymy only as a lexical relation between words rather than concepts. They support their view with the argument that 'large/little' and ' big/small' are semantically opposed, but lexically are not considered antonyms. This is further supported by Muehleisen (1997) who argues that these pairs are not true antonyms, because they do not describe the same kind of things and share different collocational profiles. Fellbaum (1995) problematizes this lexical approach by showing that antonymy holds between words within the same form class and across form classes, as in 'love/hatred', and between grammatically compatible words, as in 'loves/hates'. The caveat with the lexical approach is that it does not encompass cases of conceptual contrasts and non-canonical oppositions.

Proponents of the semantic approach comprise mainly Palmer (1981) and Crystal (1985) who view antonymy as a relation of semantic oppositeness. The problem with the semantic approach is that not all semantically opposed words are true antonyms. Native speakers of English would be reluctant to consider a pair like 'tubby/emaciated' as antonyms. A synergy of the two approaches would resolve these problems and this is the reason why contemporary semanticists prefer to combine and conflate both approaches into the so-called 'lexicalsemantic approach' (cf. Storjohann 2010). Earlier Jones (2002) has illustrated that any definition of antonymy must be lexical and semantic, synergically 'lexicosemantic' (cf. Storjohann 2010:5).

\subsubsection{Canonical vs. non-canonical}

The domestic quarrel over whether antonymy is canonical or non-canonical is the product of the friendly clash between the lexical and semantic approaches. Jones (2002:11) literally says:

Antonyms need to have 'oppositeness of meaning' (Jackson 1988:75), but they also need to have a strong, well-established lexical relationship with one another. Those word pairs which meet both criteria are known as 'prototypical' or 'canonical' antonyms; those word pairs which meet the first criterion but not the second have been dubbed 'peripheral' or 'noncanonical' (terminology provided by Cruse (1986:198) and Murphy (1994:4), respectively). These labels essentially refer to those pairs which are lexically enshrined (e.g. hard/soft) and those pairs which are not (e.g. malleable/rigid). Inevitably, the more antonymity a word pair is thought to 
have, the more linguistic attention it has received; currently favored categories of antonymy tend to be based on prototypical antonyms only.

The so-called 'canonical antonyms' are conventional opposites which hold together a lexical relation well established and well recognized by the native speakers of the languages in focus, as in 'I do not know whether to laugh or cry'. The so-called 'non-canonical antonyms' are unconventional, peripheral opposites that hold together semantic, not lexical, opposition and that would not be considered 'prototypical' antonyms in neutral contexts by the native speakers of the languages in focus, as in 'I do not know whether to play Hamlet or Macbeth'. Mettinger (1994), Jones (2002), and The Comparative Lexical Relations Group members are the proponents of the canonical approach who champion the role of syntactic frames in signaling canonical antonyms and identifying their discourse functions across Swedish (Murphy et al. 2009) and Japanese (Muehleisen and Isono 2009). There are also other subsequent studies on the textual functions of antonymy in Dutch (Lobanova et al. 2010), Serbian (Kostić 2011), Romanian (Gheltofan 2013), Classical Arabic (Hassanein 2013, 2018), Chinese (Hsu 2015), and Modern Standard Arabic (AlHedayani 2016). The non-canonical approach is extremely understudied and only Davies $(2012,2013)$ has conducted a seminal study on the roles of syntactic frames in triggering non-canonical oppositions in discourse.

\subsubsection{Syntax-free vs. syntax-dependent}

Davies (2012) points out that traditional literature categorizes dichotomously antonymous, rather oppositional, pairs in terms of context-free relations between these pairs. The categorizations are typically built on a syntax-free, form-based approach, and this seems to explain why they are stable in nature and limited in number with fairly consistent presence in language system. Two traditional classifications are normally accepted as the standard typologies, namely Lyons's (1977) and Cruse's (1986). Lyons (1977) speaks of a larger relation of opposition he calls 'contrast' and divides it into binary and non-binary contrasts. Therein antonymy is classed as a subcategory of contrasts referred to as gradable oppositions (cf. Davies 2012:44). Cruse (1986) adopts approximately the same approach by considering antonymy also as a subtype of opposites (cf. Jones 2002). The categories developed by Cruse (1986) are, as Jones (2002:13-14) states, the most comprehensive, replicating Lyons's terminology but with further complex subclasses - a statement that accords with Gorgis and Al-Halawachy (2001) who regard Cruse's taxonomy as the most adequate. Davies (2012:43-44) argues that prior studies have drawn on sentences including co-occurring opposites invented for the purpose of exemplification and illustration and not taken from actual instances of discourse.

A main problem with this approach is that it disregards opposition above word level (phrasal, clausal and sentential) and between lexical and conceptual expressions not seen as conventional antonyms. Contemporary studies have categorized antonyms and oppositions based on a co-occurrence hypothesis (Fellbaum 1995), i.e., within syntactic frameworks (' $\mathrm{X}$ and/or $\mathrm{Y}$ ') in real discourses, examined seminally by Mettinger (1994) but more extensively by Jones (2002) and Davies (2012, 2013). 


\section{Classifications}

This section reviews all the available and accessible typologies of Arabic tiba: $q$ and English antonymy but does not tend at all to be an exhaustive survey of both phenomena.

\subsection{Tiba:q classification in Arabic}

Prior classifications of tiba: $q$ in Arabic rhetoric have developed mainly from rhetoricians' endeavors to categorize the phenomenon based on the co-occurrence of antonyms in form-dependent, syntax-free environments. No comprehensive taxonomy has been proposed by a single rhetorician. Rather, one can find a category or two, but not an exhaustive list, being mentioned in every single rhetorical book.

\subsubsection{Sibawayh's categories}

Sibawayh (1988:24) classifies tiba:q into two interrelated categories, lexical tiba:q and semantic tiba:q, and typifies both with the two antonymous pairs qa:ma/jalasa 'stand/sit' and dhahaba/ja:?a 'go/come'. Based on Al-'Askari:'s (1997) and Ibn ManTHu:r's (N.D.) semantic distinctions between synonyms as $q a^{c} a d a$ (from a standing position) and jalasa (from a lying position), the former pair might be classed as a type of semicanonical semantic antonymy and the latter as a type of canonical lexical antonymy.

\subsubsection{Al-2a:midi:'s categories}

Al-Pa:midi: (1992:288) categorizes tiba:q into lexical tiba:q and semantic tiba:q, a classification shared by Al-Khafa:ji: (1982:199-202) who exemplifies the canonical lexical guise of tiba: $q$ in his poetic citation below:
a. ورَتَُّوجو هُنَّ البيض سُوداً
فرَرَّ شُعورهنَ السُود بيضاً
b. 'It turned their black hair white
And turned their white faces black'

Lexical antonymy figures prominently in the canonically opposed pairs (given in bold italics in the examples above and below) assu:d/al-bi: $\underline{d}$ 'black/white' and bi:d/su:d 'white/black', each of which is a post-modifier of the nouns shu'u:r 'hair' and wuju:h 'faces', respectively. The pairs are classified as a typical case of tiba:q attadbi:j 'variegated antonymy' in Arabic rhetoric (cf. AlQazwi:ni: 2003:258) but as a typical case of 'transitional antonymy' in English semantics (cf. Jones 2002:85).

\subsubsection{Quda:ma Ibn Ja ${ }^{c}$ far's categories}

Quda:ma Ibn Ja ${ }^{c}$ far (N.D.:147-148) classes attiba: $q$ which he prefers to term attaka:fu? into tiba:q al-Pija:b 'non-negated antonymy' and tiba:q assalb 'negated antonymy' (cf. 'non-negated antithesis/negated antithesis' in Abdul-Raof 2006:285). Tiba:q al-Pija:b refers to the co-occurrence of a pair of nonmorphologically related antonyms or opposites whereas tiba:q assalb applies to the co-occurrence of two morphologically related ones, as respectively 
exemplified below.

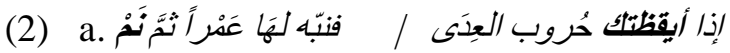

b. 'If an enemy's war awakens you | alert Amr to it and then sleep'

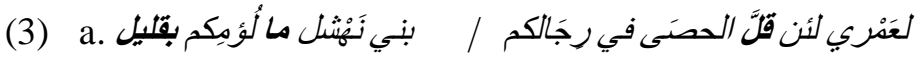

b. 'I swear on my life if the number of your men turns little, | Banu Nahshal, your guile is not little at all'

\subsubsection{Al-Qarta:janni:'s categories}

Al-Qarta:janni (2008:48-51) provides a more detailed division of tiba:q: mahd vs. ghayr mahd 'canonical vs. non-canonical' and Pija:b vs. salb 'non-negated vs. negated'. The canonical tiba:q is a lexical one in which opposition is established between a pair of lexemes and accordingly a pair of senses. The non-canonical tiba:q is, in turn, a semantic one in which opposition features between less conventionally and unconventionally opposed items. The non-negated tiba:q creates opposition between non-morphologically derived words whereas the negated tiba: $q$ is between morphologically derived ones. Each line of verse below typifies each of the categories above, respectively.

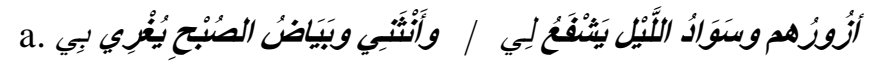

b. II visit them while the night darkness hides me | and I leave while the morning brightness discloses me'

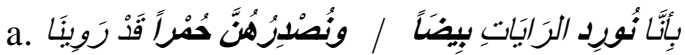

b. 'We send the flags white | and return them red, soaked in blood'

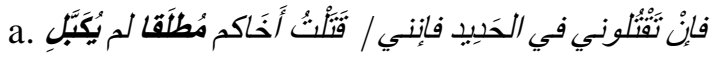

b. 'If you kill me in shackles | I killed your brother, free not shackled'

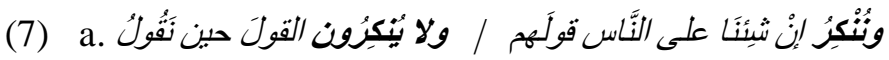
say'

b. 'We deny, if we wish, what people say | but they do not deny what we

Al-Qarta:janni (2008:51) adds another category to his typology of attiba:q, generally termed tiba:q al-tarsi $i^{c}$ 'chiasmatic antonymy', in which words or concepts are repetitively opposed in reverse orders or constructions and are accompanied by an esthetical rhetorical trope, such as 'metonymy' or 'pun'. The line of verse below is a typical example.

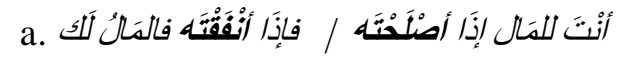

b. 'You belong to money if you keep it | but if you spend it the money becomes yours' 


\subsubsection{Al-Qazwi:ni:'s categories}

Al-Qazwi:ni: (2003:255-260) presents a more dynamic typology of attiba: $q$ and its superordinate al-muqa:bala. He (2003:255-256) classifies the former into allafTHi: 'lexical' and al-macnawi: 'semantic', which he subclassifies into two words of the same form, as in 'noun vs. noun', 'verb vs. verb' and 'particle vs. particle', or of different forms such as 'verb vs. noun'.

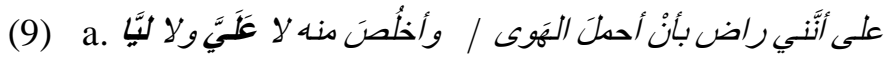
$m e^{\prime}$

b. 'That I agree to bear love | and survive it with nothing for me or against

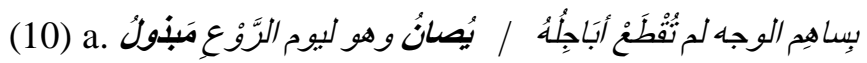

b. 'An unstable horse whose foreleg veins are still intact | is protected but an oblation on battle-days'

Al-Qazwi:ni: (2003:257) divides attiba:q into THa:hir 'patent or explicit' and khafi: 'latent or implicit'. The patent tiba: $q$ is lexically enshrined and is effortlessly easy for the readers to explore. Conversely, the latent tiba: $q$ is semantically or conceptually created and requires a quest on part of the readers to figure it out. Consider the lines of verse below.

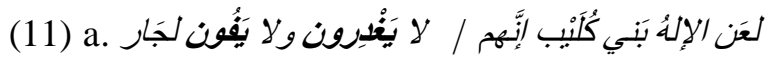

b. 'May God damn Bani Kulayb | they are neither unfaithful nor faithful to a neighbor'

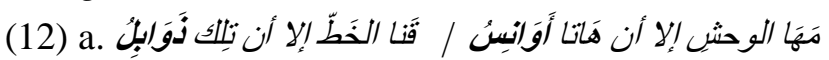

b. 'Like wildlife cows, but these are docile | Like Khatti lances, but those are dry'

Al-Qazwi:ni: (2003:257) also classifies attiba:q into tiba:q al-Pija:b 'nonnegated antonymy' and tiba:q assalb 'negated antonymy'. The former constitutes, as shown above, opposition between lexemes of distinct inflectional or derivational morphemes; the latter between two morphologically related lexemes, one is affirmative and the other is negative, or between an affirmative command and a negative command. A typical case is shown in the following line of verse.

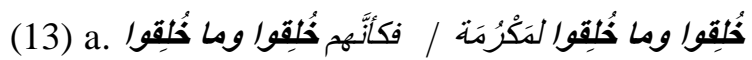

b. 'They were created but not created for a generous deed |As if they were created but not created'

Al-Qazwi:ni: (2003:258) resumes his taxonomy and continues to provide us with three other distinct categories: tiba:q attadbi:j 'variegated antonymy', tiba:q shibh-mahd 'semi-canonical antonymy' and Piha:m attada:dd 'pseudoantonymy'. The first category establishes opposition between chromatic or color 
terms for metonymic and punning purposes. The second category enshrines opposition between semi-canonically or less canonically opposed items. The third category is classified as a type of figurative antonymy, which triggers opposition between non-canonical senses or concepts carried by canonical lexemes. The three categories are respectively represented in the following lines of verse.

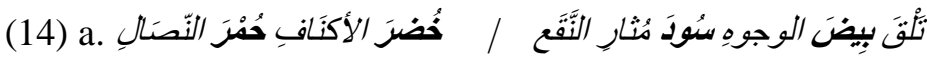

b. 'You see the white-faced blackened, stirring up dust | green on all sides with reddened blades'

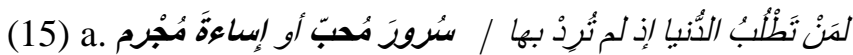

b. 'For whom you seek this life if you do not want it | to please a cherisher or maltreat a sinner'

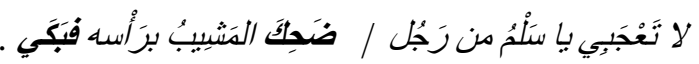

b. 'Salm, do not wonder at a man | at whose head hoariness laughed and so he cried'

Al-Qazwi:ni: (2003:259-260) broadens the scope of attiba:q to include all types of opposition that he packs into his term al-muqa:bala 'opposition'. Consequently, al-muqa:bala is more general, more comprehensive and more inclusive than attiba:q, because it brings into opposition couplets (two pairs in 17), triplets (three pairs in 18), quartets (four pairs in 19), quintets (five pairs in 20), and more. Examples (17), (18), (19), and (20) represent the sets given above. ${ }^{2}$

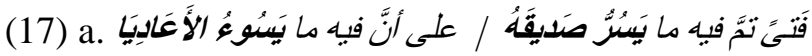
foes'

b. 'A lad who has all that pleases his friend | but has what displeases his

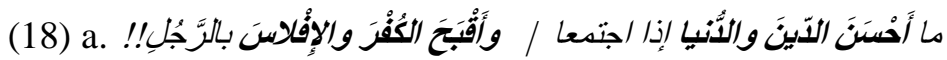

b. 'How beautiful are belief and life if they hang together | and how ugly are man's disbelief and bankruptcy!!'

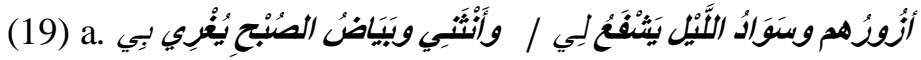

b. I visit them while the night darkness hides me | and I leave while the morning brightness discloses me'

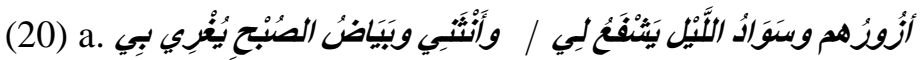

b. I visit them while the night darkness hides me | and I leave while the morning brightness discloses me'

\subsubsection{Attayyibi:'s categories}

In his definition of attiba: $q$ as bringing together two opposite meanings borne by 
two literally or non-literally opposite words, Attayyibi: (1977:194) seems to be implicit about attiba:q al-lafTHi: 'lexical antonymy' and attiba:q al-macnawi: 'semantic antonymy'. He exemplifies both categories below.

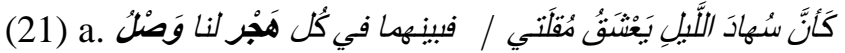

b. 'As if sleeplessness at night adores my eyeball| they strike up a relationship in between with each breakup'

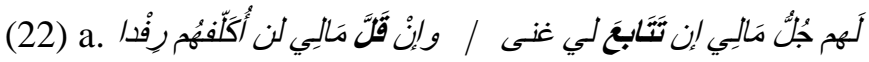

b. 'Theirs is all my money if my wealth continues | and if my money decreases, I will not ask them for an aid'

Attayyibi: (1977:197) echoes Al-Qazwi:ni: (2003:259) in widening the range and scope of attiba:q, introducing al-muqa:bala as a cover-all term for all guises of opposition, lexical and semantic or canonical and non-canonical. He provides the following lines of verse as typical cases of opposition between threes and fives (rather sixes).

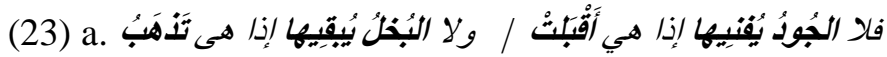

b. 'Neither would generosity stop it if it continues | nor would miserliness keep it if it discontinues'

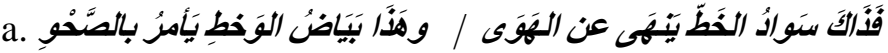
b. 'That youth blackness forbids one from fancy | and this old-age whiteness commands one to awakening'

\subsubsection{Al- ${ }^{\mathrm{C}}$ Alawi:'s categories}

Al- ${ }^{\mathrm{C}}$ Alawi: (1914:378-386) divides attatbi:q (attada:dd, attaka:fu? and attiba:q elsewhere) which he prefers to call al-muqa:bala into four configurations:

1. ashshay? bi-diddih min jihat lafTHih 'lexical antonymy',

2. ashshay? bi-diddih min jihat macna: $h$ 'semantic antonymy',

3. ashshay? bi-ma: yukha:lifuh min ghayr muda:da 'lexical contrast', and

4. ashshay? bi-ma: yuma:thiluh 'lexical analog'.

The first configuration features a canonical pair of lexical and in turn semantic opposites. The second features a canonical pair of semantic, not lexical, opposites. The third features a noncanonical pair of lexical and semantic contrasts which are not considered as opposites in neutral contexts. The fourth features a non-canonical pair of analogs or lexical repetitions in the same or parallel constructions. Such configurations can be typified as follows.

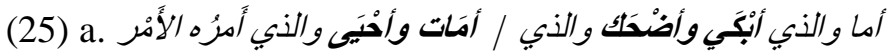


b. 'By the one who makes one cry and laugh | who makes one die and live again and who has all power'

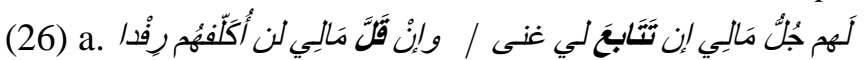

b. 'Theirs is all my money if I my wealth continues | and if my money decreases, I will not ask them for an aid'

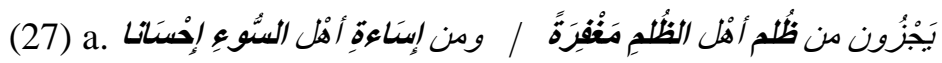

b. 'They reward injustice from the unjust with forgiveness | and evildoing from the evildoers with

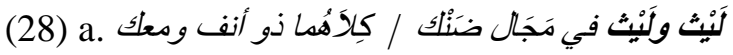
kindness'

b. 'A lion and a lion in a narrow place | both have pride and with you'

\subsubsection{Al-Madani:'s categories}

Al-Madani: (1969:33) divides attiba:q into attiba:q al-haqi:qi: 'literal antonymy' and attiba:q al-maja:zi: 'figurative antonymy', each of which falls either into attiba:q al-lafTHi: 'lexical antonymy' and attiba:q al-macnawi: 'semantic antonymy' or into tiba:q al-Pija:b 'non-negated antonymy' and tiba:q assalb 'negated antonymy'. These categories are explained in detail (see 4.1.5 and 4.1.6). So, in this section, I am prone to provide more illustrative examples from AlMadani: (1969) as follows.

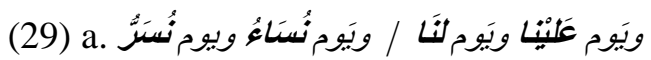

b. 'A day for us and a day against us | a day on which we are saddened and a day on which we are gladdened'

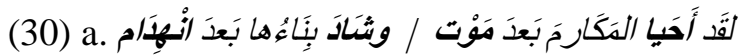

b. 'enlivened the noble manners after their death | and built them up after their destruction'

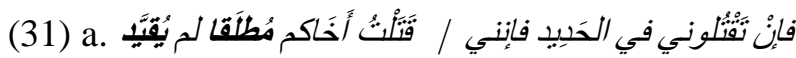

b. 'If you kill me in shackles | I killed your brother, free not shackled'

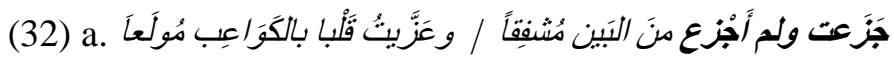

b. 'I grieved but I was not grieved by separation | and I condoled a heart fond of buxom women'

Al-Madani: (1969:42) also presents the subcategory of attiba:q al-khafi: 'latent antonymy' which features opposition between two causally or necessarily related meanings, as in example (33).

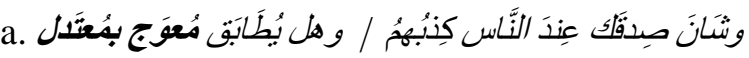


b. 'Your honesty with people was sullied by their lies | would it be fair to compare snaky to upright?'

Furthermore, Al-Madani: (1969:48-49) introduces other categories of attiba:q: tiba:q attadbi:j 'variegated antonymy' and tiba:q attarshih or attarsi $:^{.}$ 'chiasmatic antonymy'. Variegated antonymy features canonical or non-canonical opposition between two color terms. Chiasmatic antonymy dresses opposition between a pair of words with a rhetorical trope, a figure of speech, such as 'antimetabole', to add flavor and rigor to the rhetorical style. See examples (34) and (35).

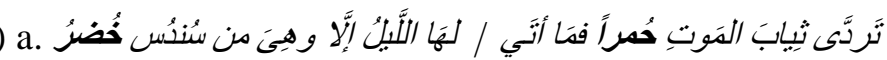

b. 'He wore the garment of death in red but when | the night fell over it, it turned green as fine silk'

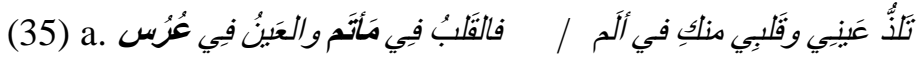

b. 'My eye delights and my heart is in agony because of you | the heart is at a funeral and the eye is at a wedding,

Putting it all together, I am prone to echo Al-Jamma:s (2002) who pieced together the previously presented categories of attiba: $q$ from Arabic rhetorical sources. The categories pieced together are summarized in Table 1.

Table 1: An outline of attiba:q categories as collected from Arabic sources (AlJamma:s 2002)

\begin{tabular}{|c|c|c|c|c|}
\hline \multicolumn{2}{|c|}{ Category } & Definition & \multicolumn{2}{|c|}{ Pair } \\
\hline lafTHi: & 'lexical' & between words & hayy/mayyit & 'living/dead' \\
\hline haqi:qi: & 'literal' & $\begin{array}{l}\text { between } \\
\text { canonical } \\
\text { words }\end{array}$ & $\begin{array}{l}\text { Payqa:dh/ruqu: } \\
\text { d }\end{array}$ & 'awake/asleep' \\
\hline Pija:bi: & 'nonnegated & $\begin{array}{l}\text { between } \\
\text { morphemically } \\
\text { unrelated } \\
\text { words }\end{array}$ & laha:/calayha: & 'for/against' \\
\hline salbi: & 'negated' & $\begin{array}{l}\text { between } \\
\text { morphologicall } \\
\text { y related words }\end{array}$ & $\begin{array}{l}\text { taclam/la } \\
\text { ?aclam }\end{array}$ & 'know/not know' \\
\hline maja:zi: & 'figurative' & $\begin{array}{l}\text { between } \\
\text { nonliteral } \\
\text { meanings }\end{array}$ & mayt/Pahyayna: & 'dead/render alive' \\
\hline$m a^{c}$ nawi: & 'semantic' & between & qisas $/ \underline{h a y a . t}$ & 'retribution/life' \\
\hline
\end{tabular}




\begin{tabular}{|c|c|c|c|c|}
\hline & & $\begin{array}{l}\text { meanings or } \\
\text { senses }\end{array}$ & & \\
\hline khafi: & 'latent' & $\begin{array}{l}\text { between } \\
\text { concepts }\end{array}$ & $\begin{array}{l}\text { Pughriqu:/ } \\
\text { Pudkhilu: }\end{array}$ & 'be drowned/cast' \\
\hline Piha:mi: & 'pseudo' & $\begin{array}{l}\text { between } \\
\text { concepts }\end{array}$ & maghfira/ adl & $\begin{array}{l}\text { 'forgiveness/justic } \\
\text { e' }\end{array}$ \\
\hline tadbi:ji: & 'variegated' & between colors & $b i: \underline{d} / s u: d$ & 'white/black' \\
\hline $\begin{array}{l}\operatorname{tarshi}:{ }^{h} i: \\
\text { tarsi: }\end{array}$ & 'chiasmatic' & $\begin{array}{l}\text { between } \\
\text { rhetorically } \\
\text { troped words }\end{array}$ & layl/naha:r & 'night/day' \\
\hline
\end{tabular}

\subsubsection{AlHedayani's categories}

AlHedayani (2016) categorizes attiba:q 'antonymy' afresh based on the discourse functions it serves in Modern Standard Arabic (MSA) discourse and cooccurrences of such functions in parallel syntactic environments. Building on an analysis of two corpora, arTenTen12 and arabiCorpus, and on the typologies of Jones (2002) and Davies (2013), she quantifies different classifications with examples and arranges them in a descending order from the most frequent to the least frequent. Table 2 quantifies and typifies her categories.

Table 2: An outline of AlHedayani's (2016) categories of attiba:q 'antonymy' in MSA

\begin{tabular}{|c|c|c|c|c|}
\hline \multirow{2}{*}{\multicolumn{2}{|c|}{\begin{tabular}{l|l} 
Category & Subcategory \\
Inclusiveness
\end{tabular}}} & Definition & \multicolumn{2}{|c|}{ Example } \\
\hline & & $\begin{array}{l}\text { coordinates } \\
\text { an antonym } \\
\text { with another } \\
\text { to include } \\
\text { and exhaust } \\
\text { a scale }\end{array}$ & khafi:f/thaqi:l & 'light/heavy' \\
\hline Antithesis & & $\begin{array}{l}\text { opposes } \\
\text { phrasal or } \\
\text { clausal } \\
\text { coordinate } \\
\text { propositions }\end{array}$ & $\begin{array}{l}\text { ma: ?uhib/ma: } \\
\text { Pakrah }\end{array}$ & $\begin{array}{l}\text { 'what I love/what } \\
\text { I hate' }\end{array}$ \\
\hline Transitive & & $\begin{array}{l}\text { opposes } \\
\text { VSO } \\
\text { nominal } \\
\text { antonyms or } \\
\text { SV } \\
\text { adjectival } \\
\text { antonyms }\end{array}$ & $\begin{array}{l}\text { al- } \\
\text { qawiyy/add } a^{c} i: f\end{array}$ & $\begin{array}{l}\text { 'the strong/the } \\
\text { weak' }\end{array}$ \\
\hline Substantive & & $\begin{array}{l}\text { contrasts } \\
\text { nominal or } \\
\text { adjectival } \\
\text { antonyms in } \\
\text { equational }\end{array}$ & $\begin{array}{l}\text { adhdhuku:r/al- } \\
\text { Pina:th }\end{array}$ & 'males/females' \\
\hline
\end{tabular}




\begin{tabular}{|c|c|c|c|c|}
\hline & sentences & & \\
\hline \multicolumn{2}{|l|}{ Verbal } & $\begin{array}{l}\text { contrasts } \\
\text { antonyms in } \\
\text { a VO } \\
\text { structure }\end{array}$ & yukhaffif/thiqa:l & 'lighten/heaviness \\
\hline \multirow[t]{3}{*}{$\begin{array}{l}\text { Compariso } \\
\mathrm{n}\end{array}$} & Direct & $\begin{array}{l}\text { measures } \\
\text { one } \\
\text { antonym } \\
\text { against the } \\
\text { other } \\
\text { directly }\end{array}$ & tadhki:r/ta?ni:th & $\begin{array}{l}\text { 'masculinization/ } \\
\text { femininization' }\end{array}$ \\
\hline & Equal & $\begin{array}{l}\text { balances one } \\
\text { antonym } \\
\text { against the } \\
\text { other with } \\
\text { equal } \\
\text { weight }\end{array}$ & niha:ya/bida:ya & 'end/beginning' \\
\hline & Unequal & $\begin{array}{l}\text { balances one } \\
\text { antonym } \\
\text { against the } \\
\text { other with } \\
\text { unequal } \\
\text { weight }\end{array}$ & $\begin{array}{l}\text { al-ya:bis/al- } \\
\text { ma:? }\end{array}$ & 'land/water' \\
\hline \multicolumn{2}{|c|}{ Subordination } & $\begin{array}{l}\text { subordinates } \\
\text { an antonym } \\
\text { to another } \\
\text { using a } \\
\text { subordinator }\end{array}$ & $\begin{array}{l}\text { al- } \\
\text { qawiyy/add } a^{c} i: f\end{array}$ & $\begin{array}{l}\text { 'the strong / the } \\
\text { weak' }\end{array}$ \\
\hline \multicolumn{2}{|l|}{ Emphasis } & $\begin{array}{l}\text { negates a Y- } \\
\text { antonym in } \\
\text { favor of the } \\
\text { X-antonym }\end{array}$ & $q u w w a / d a^{c} f$ & $\begin{array}{l}\text { 'strength/weaknes } \\
\text { s' }\end{array}$ \\
\hline \multicolumn{2}{|l|}{ Correction } & $\begin{array}{l}\text { negates an } \\
X \text {-antonym } \\
\text { in favor of } \\
\text { the Y- } \\
\text { antonym }\end{array}$ & niha:ya/bida:ya & 'end/beginning' \\
\hline \multicolumn{2}{|l|}{ Cancelation } & $\begin{array}{l}\text { negates both } \\
\text { antonyms } \\
\text { using a } \\
\text { correlative } \\
\text { negator }\end{array}$ & fawz/khusa:ra & 'win/lose' \\
\hline \multicolumn{2}{|l|}{ Transition } & $\begin{array}{l}\text { signals } \\
\text { movement } \\
\text { from one } \\
\text { antonymous } \\
\text { state to }\end{array}$ & faqr/ghina: & poverty/wealth \\
\hline
\end{tabular}




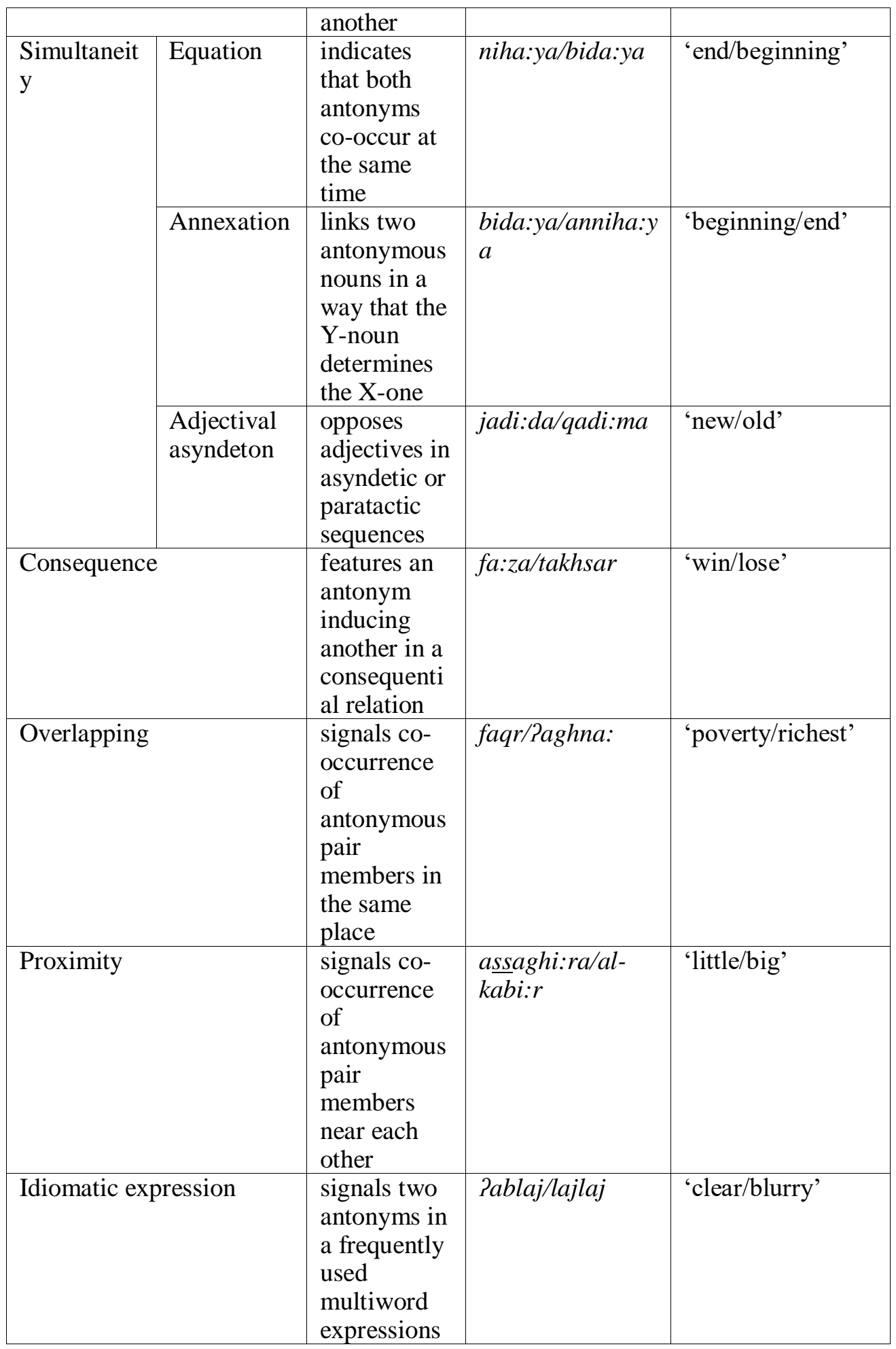




\begin{tabular}{|c|c|c|c|c|}
\hline \multicolumn{2}{|l|}{ Concession } & $\begin{array}{l}\text { contrasts } \\
\text { antonymous } \\
\text { statements } \\
\text { with } \\
\text { adversative } \\
\text { connectors }\end{array}$ & saghi:ra/takbur & 'small/grow' \\
\hline \multicolumn{2}{|c|}{ Specification } & $\begin{array}{l}\text { signals a } \\
\text { number } \\
\text { quantifying } \\
\text { the } \\
\text { antonymous } \\
\text { pair }\end{array}$ & dhakar/Puntha: & 'males/females' \\
\hline \multicolumn{2}{|l|}{ Unity } & $\begin{array}{l}\text { treats the } \\
\text { antonymous } \\
\text { pair as a } \\
\text { unit not as } \\
\text { two separate } \\
\text { words }\end{array}$ & $a l-q u w w a / a d d a^{c} f$ & $\begin{array}{l}\text { 'strength/weaknes } \\
\text { s' }\end{array}$ \\
\hline \multicolumn{2}{|l|}{ Distinction } & $\begin{array}{l}\text { signals a } \\
\text { semantic } \\
\text { dissimilarity } \\
\text { between two } \\
\text { antonyms }\end{array}$ & $\begin{array}{l}\text { al-?aghniya:?/al- } \\
\text { fuqara:? }\end{array}$ & 'the rich/the poor' \\
\hline \multicolumn{2}{|l|}{ Association } & $\begin{array}{l}\text { refers to a } \\
\text { link or a tie } \\
\text { between the } \\
\text { two } \\
\text { antonyms }\end{array}$ & $\begin{array}{l}\text { assaghi:ra/al- } \\
\text { kabi:ra }\end{array}$ & 'small/big' \\
\hline \multicolumn{2}{|l|}{ Conflict } & $\begin{array}{l}\text { presents an } \\
\text { antonym in } \\
\text { direct } \\
\text { conflict with } \\
\text { another }\end{array}$ & al-haqq/al-ba:till & 'right/wrong' \\
\hline \multicolumn{2}{|l|}{ Replacive } & $\begin{array}{l}\text { signals a } \\
\text { pair in } \\
\text { which one } \\
\text { antonym } \\
\text { substitutes } \\
\text { another }\end{array}$ & al-kha: $\underline{s} / a l-^{c} a: m$ & 'private/public' \\
\hline \multirow[t]{2}{*}{$\begin{array}{l}\text { Binarized } \\
\text { option }\end{array}$} & $\begin{array}{l}\text { Interrogativ } \\
\mathrm{e}\end{array}$ & $\begin{array}{l}\text { forces a } \\
\text { choice } \\
\text { between } \\
\text { antonyms in } \\
\text { an } \\
\text { interrogative } \\
\text { sentence }\end{array}$ & assala:m/al-harb & 'peace/war' \\
\hline & Non- & signals a & fa:?iz/kha:sir & 'winner/loser' \\
\hline
\end{tabular}




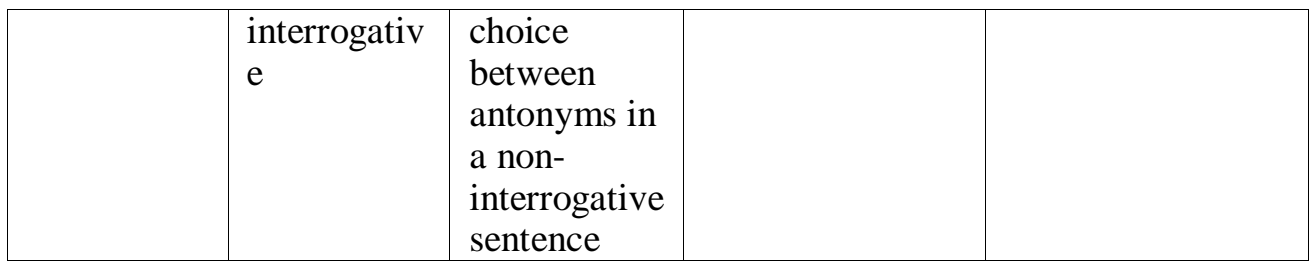

\subsubsection{Hassanein's Categories}

Hassanein $(2013,2018)$ approaches attiba:q in Classical Arabic genres (AlQurPa:n and Al-Hadi:th) anew and reclassifies it, devising two almost analogous typologies based on western perspectives. He has retrieved the taxonomy created by Jones (2002) and followed his pathway in applying this taxonomy to an entire dataset manually collected from Al-Qur?a:n, replicating and contributing new data-driven (sub)categories. In a later study (2018) drawing on fuller and larger datasets manually driven from the major canons of prophetic Hadi:th (Sahi:h AlBukha:ri: and Sahi:h Muslim), Hassanein has rigorously synergized Jones's (2002) and Davies's (2012) typologies, applying the synergized typology and analyzing typical cases thereof. Tables 3 and 4 show the developed typologies with definitions and examples.

Table 3: Hassanein's (2013) typology of attiba:q 'antonymy' in Al-Qur?a:n (adapted from Hassanein 2018)

\begin{tabular}{|l|l|l|l|l|}
\hline Category & Description & Frame & \multicolumn{2}{|c|}{ Example } \\
\hline Ancillary & $\begin{array}{l}\text { signals } \\
\text { another } \\
\text { textual or } \\
\text { metatextual } \\
\text { X/Y pair }\end{array}$ & $\begin{array}{l}\text { Transcategor } \\
\text { ial }\end{array}$ & $\begin{array}{l}\text { al-qulu:b/al- } \\
\text { Pabsa:r }\end{array}$ & 'hearts/eyes' \\
\hline $\begin{array}{l}\text { Coordinate } \\
\text { d }\end{array}$ & $\begin{array}{l}\text { joins X/Y } \\
\text { inclusively } \\
\text { or } \\
\text { exhaustivel } \\
\text { y }\end{array}$ & X and/or Y & $\begin{array}{l}\text { al- } \\
\text { samawa:t/al- } \\
\text { Pard }\end{array}$ & 'heavens/earth' \\
\hline $\begin{array}{l}\text { Comparativ } \\
\text { e }\end{array}$ & $\begin{array}{l}\text { measures X } \\
\text { against Y } \\
\text { in a } \\
\text { comparativ } \\
\text { e context }\end{array}$ & Y adj-er than & $\begin{array}{l}\text { al-Pa:khira/al- } \\
\text { Pu:la: }\end{array}$ & 'first/last' \\
\hline $\begin{array}{l}\text { Distinguish } \\
\text { ed }\end{array}$ & $\begin{array}{l}\text { draws some } \\
\text { distinction } \\
\text { between X } \\
\text { and Y }\end{array}$ & Ynow X from & $\begin{array}{l}\text { al- } \\
\text { khabi:th/attayyi } \\
\text { b }\end{array}$ & 'bad/good' \\
\hline Transitional & $\begin{array}{l}\text { makes a } \\
\text { shift in }\end{array}$ & from X to Y & $\begin{array}{l}\text { al- } \\
\text { layl/annaha:r }\end{array}$ & 'night/day' \\
\hline
\end{tabular}




\begin{tabular}{|c|c|c|c|c|}
\hline & $\begin{array}{l}\text { time, place } \\
\text { or state } \\
\text { from X to } \\
\text { Y }\end{array}$ & & & \\
\hline Negated & $\begin{array}{l}\text { negates } X \\
\text { in favor of } \\
Y\end{array}$ & $\mathrm{X}$ but not $\mathrm{Y}$ & $\begin{array}{l}\text { Pamwa:t/Pahya } \\
\text { ?? }\end{array}$ & 'dead/alive' \\
\hline Extreme & $\begin{array}{l}\text { places X/Y } \\
\text { as extremes } \\
\text { on a } \\
\text { continuum }\end{array}$ & $\begin{array}{l}\text { too } \mathrm{X} \text { and } \\
\text { too } \mathrm{Y}\end{array}$ & fura:t/Puja:j & $\begin{array}{l}\text { 'too fresh/too } \\
\text { salty' }\end{array}$ \\
\hline Idiomatic & $\begin{array}{l}\text { spots X/Y } \\
\text { in } \\
\text { idiomatic } \\
\text { set phrases }\end{array}$ & $\begin{array}{l}\text { Transcategor } \\
\text { ial }\end{array}$ & $\begin{array}{l}{ }^{c} a: l i: h a: / s a: f i l i \\
\text { ha: }\end{array}$ & 'upside/down' \\
\hline $\begin{array}{l}\text { Subordinate } \\
\text { d }\end{array}$ & $\begin{array}{l}\operatorname{logs} \mathrm{X} / \mathrm{Y} \text { in } \\
\text { subordinate } \\
\text { - } \\
\text { superordina } \\
\text { te clauses }\end{array}$ & if $\mathrm{X}$ then $\mathrm{Y}$ & ${ }^{c}$ usra:/maysara & 'difficulty/ease' \\
\hline Exchanged & $\begin{array}{l}\text { exchanges } \\
X \text { for } Y \text { in } \\
\text { a } \\
\text { transaction } \\
\text { al context }\end{array}$ & buy $\mathrm{X}$ for $\mathrm{Y}$ & $\begin{array}{l}\text { addala:la/al- } \\
\text { huda: }\end{array}$ & 'error/guidance' \\
\hline Case & $\begin{array}{l}\text { signals case } \\
\text { roles } \\
\text { played by } \\
\text { X or Y or } \\
\text { both }\end{array}$ & $\begin{array}{l}\text { Transcategor } \\
\text { ial }\end{array}$ & $\begin{array}{l}\text { atta:lib/al- } \\
\text { matlu:b }\end{array}$ & $\begin{array}{l}\text { 'petitioner/petition } \\
\text { ed' }\end{array}$ \\
\hline
\end{tabular}

Table 4: Hassanein's (2018) typology of attiba:q/al-muqa:bala 'antonymy/opposition' in Al- Hadi:th

\begin{tabular}{|l|l|l|}
\hline Category & Discourse function & Syntactic frame \\
\hline $\begin{array}{l}\text { Ancillary } \\
\text { opposition }\end{array}$ & $\begin{array}{l}\text { signals an intratextual contrast between a } \\
\text { pair of words that aims mainly for a larger } \\
\text { intratextual or metatextual contrast between } \\
\text { another pair }\end{array}$ & transcategorial \\
\hline $\begin{array}{l}\text { Transitional } \\
\text { opposition }\end{array}$ & $\begin{array}{l}\text { signals co-occurrence of a contrastive pair } \\
\text { within a framework that expresses a change } \\
\text { in place, time and state }\end{array}$ & from X to Y \\
\hline $\begin{array}{l}\text { Comparative } \\
\text { opposition }\end{array}$ & $\begin{array}{l}\text { signals co-occurrence of a contrastive pair } \\
\text { within a framework that positions its }\end{array}$ & $\mathrm{X}$ [adj-]er than Y \\
\hline
\end{tabular}




\begin{tabular}{|c|c|c|}
\hline & $\begin{array}{l}\text { members in a comparative context gauging } \\
\text { one opposite against the other }\end{array}$ & \\
\hline $\begin{array}{l}\text { Replacive } \\
\text { opposition }\end{array}$ & $\begin{array}{l}\text { signals co-occurrence of a contrastive pair } \\
\text { within a framework in which a member is } \\
\text { exchanged or substituted for its opposite }\end{array}$ & $\mathrm{X}$ in return for $\mathrm{Y}$ \\
\hline $\begin{array}{l}\text { Sub-ordinated } \\
\text { opposition }\end{array}$ & $\begin{array}{l}\text { signals co-occurrence of a contrastive pair } \\
\text { within two clauses joined in a sub-ordinate } \\
\text { conditional, concessive, temporal or } \\
\text { circumstantial context }\end{array}$ & if $X$ then $Y$ \\
\hline $\begin{array}{l}\text { Co-ordinated } \\
\text { opposition }\end{array}$ & $\begin{array}{l}\text { signals co-occurrence of a contrastive pair } \\
\text { within a frame joining two opposites in a } \\
\text { co-ordinate junctive or disjunctive context }\end{array}$ & $\mathrm{X}$ and $\mathrm{Y}$ \\
\hline $\begin{array}{l}\text { Distinguished } \\
\text { opposition }\end{array}$ & $\begin{array}{l}\text { signals co-occurrence of a contrastive pair } \\
\text { within a framework that draws an implicit } \\
\text { or explicit semantic distinction between its } \\
\text { members }\end{array}$ & $\begin{array}{l}\text { v/n X } \\
\text { from/between Y }\end{array}$ \\
\hline $\begin{array}{l}\text { Extreme } \\
\text { opposition }\end{array}$ & $\begin{array}{l}\text { signals co-occurrence of a contrastive pair } \\
\text { within a framework that moves between two } \\
\text { extremes on a given scale }\end{array}$ & too $\mathrm{X}$ too $\mathrm{Y}$ \\
\hline $\begin{array}{l}\text { Idiomatic } \\
\text { opposition }\end{array}$ & $\begin{array}{l}\text { signals co-occurrence of a contrastive pair } \\
\text { within a framework treated as a set phrase } \\
\text { whose constituents, at least one if not both, } \\
\text { function idiomatically }\end{array}$ & transcategorial \\
\hline $\begin{array}{l}\text { Negated } \\
\text { opposition }\end{array}$ & $\begin{array}{l}\text { signals co-occurrence of a contrastive pair } \\
\text { within a framework that negates one } \\
\text { opposite in favor of the other }\end{array}$ & not $X$ but $Y$ \\
\hline $\begin{array}{l}\text { Interrogative } \\
\text { opposition }\end{array}$ & $\begin{array}{l}\text { signals co-occurrence of a contrastive pair } \\
\text { in an interrogative, usually disjunctive, } \\
\text { context to request factual information or } \\
\text { show preference }\end{array}$ & $\mathrm{X}$ or $\mathrm{Y} ?$ \\
\hline $\begin{array}{l}\text { Case-marked } \\
\text { opposition }\end{array}$ & $\begin{array}{l}\text { signals co-occurrence of a contrastive pair } \\
\text { within a framework that expresses case } \\
\text { roles played by one of its contrastive } \\
\text { members or by both }\end{array}$ & neither $\mathrm{X}$ nor $\mathrm{Y}$ \\
\hline
\end{tabular}

\subsection{Antonymy Classification in English}

Classical or traditional typologies of antonymy in English semantics have all drawn upon form-dependent and context-free criteria of classification. Conversely, modern or contemporary ones have mostly drawn on function-based and context-dependent criteria. Davies $(2012,2013)$ highlights the dichotomy of context-free and context-dependent categorizations and literally states that traditional studies tend to categorize oppositional types according to a context-free relationship between the oppositional pairs. These studies, except a few ones, have mostly focused on opposite pairs in a syntax-free environment containing co-occurring opposites invented for the purpose of classification and illustration. 
The opposites have inherent and intrinsic oppositions, independent of their usage in actual stretches of discourse, and the result is a limited and stable set of pairs with independent presence in language systems. Contemporary studies swim against the stream and tend to classify oppositions according to their cooccurrences in common syntactic frames mentioned in passing by Fellbaum (1995), in more detail by Mettinger (1994), in some detail by Jeffries (1998) and in the most extensive detail by Jones (2002) in his seminal corpus-based study.

\subsubsection{Aristotle's Categories}

The birth of antonym categorization seems to have implicitly appeared in Aristotle's 'Square of Opposition' (cf. Correia 2017). In their survey of the classical and structuralist perspectives on antonymy, Murphy et al. (2009:6) argue that much modern thought on antonymy dates back to the categories of propositional opposition developed by Aristotle who devised this diagrammatic representation of universalistic and particularistic affirmations and negations and introduced a range of typological terminologies, e.g., contraries and contradictories, that have been adopted in linguistics until today. Correia (2017:2) implies that Aristotle has employed both horizontal and oblique lines to divide opposition into contraries, contradictories, and subcontraries, but he has ignored vertical lines (A-I and E-O relations), as Figure 1 shows.

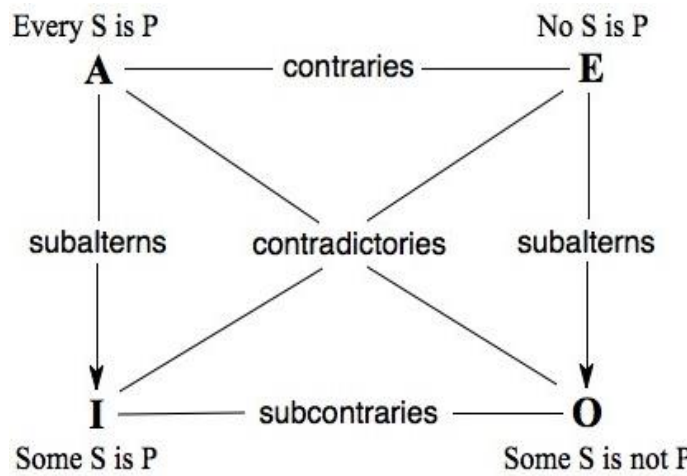

Figure 1: Aristotelian categories of opposition (adapted from Correia 2017:2)

Contraries feature a category in which contrary statements cannot both be true at the same time. Contradictories feature a category in which one contradictory statement may be true and the other false. Subcontraries feature a category in which both statements can be true but not false. A fourth category which is hinted at by Aristotle is that of implication in which a universal statement implies a particular one. Table 5 illustrates these categories with examples.

Table 5: Aristotelian categories of opposition (adapted from Correia 2017:3-9)

\begin{tabular}{|l|l|l|l|l|}
\hline Symbol & \multicolumn{2}{|c|}{ Category } & Definition & Example \\
\hline AE & Contraries & $\begin{array}{l}\text { Universal } \\
\text { Affirmative }\end{array}$ & Every S is P & $\begin{array}{l}\text { Every man is } \\
\text { wise }\end{array}$ \\
\hline
\end{tabular}




\begin{tabular}{|c|c|c|c|c|}
\hline $\mathrm{AE}$ & & $\begin{array}{l}\text { Universal } \\
\text { Negative }\end{array}$ & No $\mathrm{S}$ is $\mathrm{P}$ & No man is wise \\
\hline IO & \multirow[t]{2}{*}{ Subcontraries } & $\begin{array}{l}\text { Particular } \\
\text { Affirmative }\end{array}$ & Some $\mathrm{S}$ is $\mathrm{P}$ & $\begin{array}{l}\text { Some man is } \\
\text { wise }\end{array}$ \\
\hline IO & & $\begin{array}{l}\text { Particular } \\
\text { Negative }\end{array}$ & $\begin{array}{l}\text { Some } \mathrm{S} \text { is not } \\
\mathrm{P}\end{array}$ & $\begin{array}{l}\text { Some man is } \\
\text { not wise }\end{array}$ \\
\hline $\mathrm{AO}$ & \multirow[t]{2}{*}{ Contradictories } & $\begin{array}{l}\text { Universal } \\
\text { Affirmative }\end{array}$ & $\begin{array}{l}\text { Not every } \mathrm{S} \text { is } \\
\mathrm{P}\end{array}$ & $\begin{array}{l}\text { Not every man } \\
\text { is wise }\end{array}$ \\
\hline $\mathrm{AO}$ & & $\begin{array}{l}\text { Particular } \\
\text { Negative }\end{array}$ & $\begin{array}{l}\text { Some } \mathrm{S} \text { is not } \\
\mathrm{P}\end{array}$ & $\begin{array}{l}\text { Some man is } \\
\text { not wise }\end{array}$ \\
\hline AI & \multirow[t]{2}{*}{ Implicatories } & $\begin{array}{l}\text { Universal } \\
\text { Affirmative } \\
\text { or Negative }\end{array}$ & $\begin{array}{l}\text { Every } \mathrm{S} \text { is } \mathrm{P} \\
\text { Some } \mathrm{S} \text { is } \mathrm{P}\end{array}$ & $\begin{array}{l}\text { Every man is } \\
\text { wise } \\
\text { Some man is } \\
\text { wise }\end{array}$ \\
\hline EO & & $\begin{array}{l}\text { Particular } \\
\text { affirmative } \\
\text { or negative }\end{array}$ & $\begin{array}{l}\text { No } S \text { is } P \\
\text { Some } S \text { is not } \\
P\end{array}$ & $\begin{array}{l}\text { No man is wise } \\
\text { Some man is } \\
\text { not wise }\end{array}$ \\
\hline
\end{tabular}

\subsubsection{Lyons's categories}

Lyons (1977:270-290) classifies opposites according to a context-free relation between the opposite pair members. He distinguishes between binary contrast and non-binary contrast. Binary contrast establishes opposition between single pairs and falls into gradable opposites (antonyms), non-gradable opposites (complementaries), directionals (orthogonal and antipodal), and converses (relationals). Non-binary contrast holds in trinary or multinary (sub) sets of three or more (cycles and series (scales and ranks)). ${ }^{3}$ Table 6 sketches and typifies the Lyonsian categories.

Table 6: Lyons's (1977) categories of opposites (adapted from Davies 2012:44)

\begin{tabular}{|c|c|c|c|c|}
\hline Category & Subcategory & Subset & Definition & Examples \\
\hline \multirow[t]{5}{*}{ Binaries } & \multicolumn{2}{|l|}{ Gradables } & $\begin{array}{l}\text { dividing a field } \\
\text { into binary } \\
\text { extremes }\end{array}$ & 'hot/cold' \\
\hline & \multicolumn{2}{|l|}{ Nongradables } & $\begin{array}{l}\text { dividing a field } \\
\text { into mutually } \\
\text { exclusive parts }\end{array}$ & 'man/woman' \\
\hline & \multirow[t]{2}{*}{ Directionals } & Orthogonal & $\begin{array}{l}\text { dividing a field } \\
\text { into perpendicular } \\
\text { points }\end{array}$ & 'north/west' \\
\hline & & Antipodal & $\begin{array}{l}\text { dividing a field } \\
\text { into diametrical } \\
\text { points }\end{array}$ & 'north/south' \\
\hline & \multicolumn{2}{|l|}{ Converses } & $\begin{array}{l}\text { dividing a field } \\
\text { into mutually } \\
\text { relational } \\
\text { opposites }\end{array}$ & 'husband/wife' \\
\hline Nonbinaries & \multicolumn{2}{|l|}{ Cycles } & dividing a field & 'spring, \\
\hline
\end{tabular}




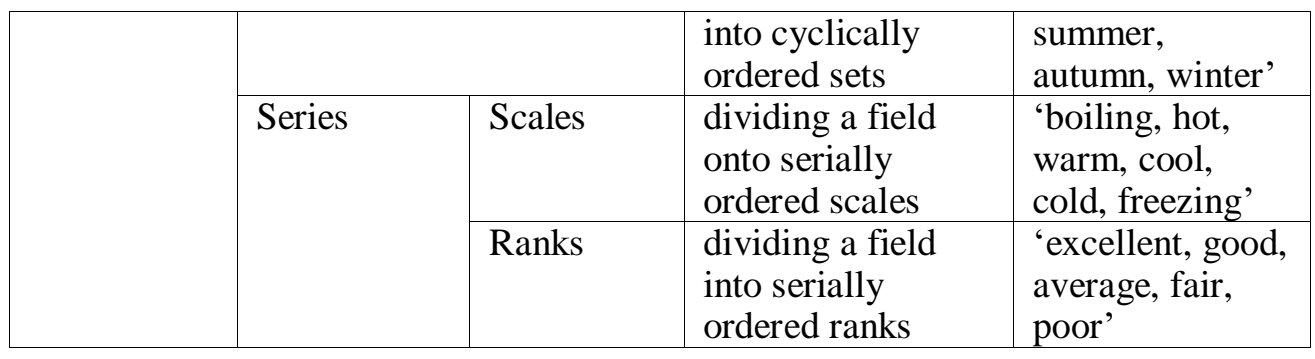

\subsubsection{Cruse's categories}

For Cruse (1986), antonymy is also a subtype of opposites, besides complementaries, converses, and reversives (cf. Jones 2002). The traditional categories devised by Cruse (1986) are, as Jones (2002) and Gorgis and AlHalawachy (2001) state, the most comprehensive and most adequate, replicating Lyons's terminology but creating further complex subclasses.

According to Cruse (1986:198), the essence of complementaries is that they exhaustively divide a semantic domain into two mutually exclusive compartments, so that what does not fall into one of them must necessarily fall into the other, without 'no-man's-hand', no neutral region and no possibility of a third term or 'sitting on the fence' in between. Cruse (2000:168) gives 'complementarity' a strict logical definition in that $\mathrm{F}(\mathrm{X})$ entails and is entailed by not-F(Y), i.e. "not being one entails being the other" (cf. Murphy 2003:29) and "dividing the domain without remainder" (cf. Griffiths 2006:28). Conversive antonyms are relational antonyms by which one yields the same proposition as the other when the arguments are reversed. Cruse (1986:234) distinguishes between direct converses (two arguments) and indirect converses (three arguments). Cruse (1986:226) refers to opposites including such verbs denoting motion or change (concrete/abstract) in opposite directions as reversives that fall into two groups: independent reversives and restitutives. Cruse (2000:171) argues that reversives are all verbs, an argument supported by Murphy (2003:197) who holds that reversive opposition involves the undoing of an action, state, or quality. Table 7 sums up the Crusian categories.

Table 7: Cruse's (1986) categories of opposites (adapted from Jones et al. 2012:7)

\begin{tabular}{|l|l|l|l|l|}
\hline Category & Subcategory & Subset & Definition & Examples \\
\hline \multirow{2}{*}{$\begin{array}{l}\text { Opposites } \\
\text { I }\end{array}$} & \multicolumn{2}{|l|}{ Complementaries } & $\begin{array}{l}\text { dividing a domain in } \\
\text { two exclusive } \\
\text { subdomains }\end{array}$ & 'true/false' \\
\cline { 2 - 5 } & Antonyms & $\begin{array}{l}\text { denoting gradation } \\
\text { of some property }\end{array}$ & 'fast/slow' \\
\hline $\begin{array}{l}\text { Opposites } \\
\text { II }\end{array}$ & Directionals & Reversives & $\begin{array}{l}\text { denoting change or } \\
\text { motion in opposite } \\
\text { direction }\end{array}$ & 'fill/empty' \\
\cline { 4 - 6 } & Restitutives & $\begin{array}{l}\text { denoting restitution } \\
\text { of a former state }\end{array}$ & 'damage/repair' \\
\cline { 3 - 6 } & representing two & 'top/bottom' \\
\cline { 2 - 5 } & Antipodals & & \\
\hline
\end{tabular}




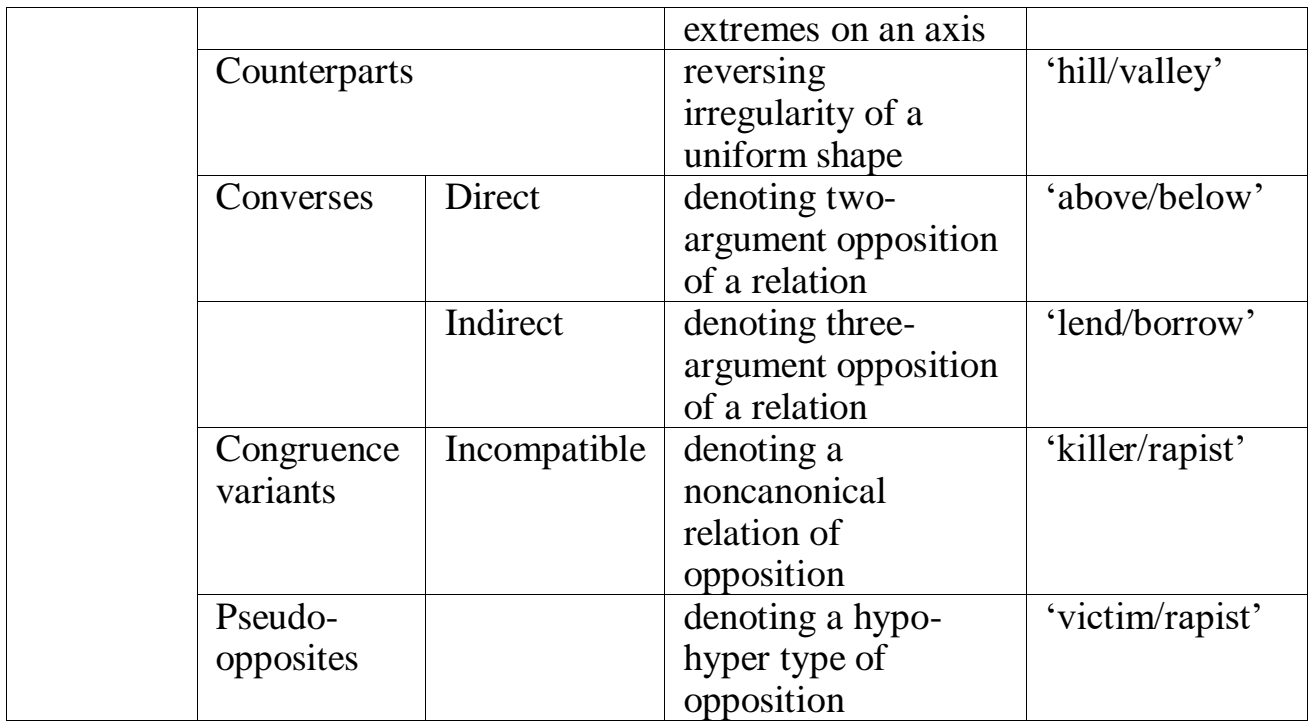

\subsubsection{Mettinger's categories}

Mettinger's (1994) pioneering study proves antonymy, rather its broader term 'opposition', to be syntactically receptive to text-based and data-driven classification. Mettinger categorizes the syntactic environments of both relations into nine frames and ascribes a textual function to each frame. Drawing upon genre-specific corpora to identify common syntactic milieus in which his cooccurring opposites (99 of 161) appear, he has been able to allocate a discourse function to each frame, such as frame A, frame B, and so forth. Table 8 tabulates Mettinger's frames with functions and instances.

Table 8: Mettinger's (1994) categories of opposites (adapted from Hassanein 2018:22)

\begin{tabular}{|l|l|l|}
\hline Key frame & Key function(s) & Key example \\
\hline A1: X and Y & $\begin{array}{l}\text { (A): simultaneous } \\
\text { validity }\end{array}$ & A clear case of cause and effect \\
\cline { 2 - 3 } & (B): confrontation & His former and his present wife \\
\hline $\begin{array}{l}\text { A1: X, at the } \\
\text { same time Y }\end{array}$ & $\begin{array}{l}\text { (A): simultaneous } \\
\text { validity }\end{array}$ & $\begin{array}{l}\text { I was puzzled by the simplicity and } \\
\text { at the same time by the complexity }\end{array}$ \\
\hline $\begin{array}{l}\text { B: neither X } \\
\text { nor Y }\end{array}$ & $\begin{array}{l}\text { (A): simultaneous non- } \\
\text { validity }\end{array}$ & $\begin{array}{l}\text { The children seem neither old } \\
\text { enough nor young enough for it. }\end{array}$ \\
\hline C: X or Y & (C): (exclusive) choice & $\begin{array}{l}\text { Is he deafer or blinder or fatter or } \\
\text { thinner? }\end{array}$ \\
\hline $\begin{array}{l}\text { D: X or }(= \\
\text { "and") Y }\end{array}$ & $\begin{array}{l}\text { (A): simultaneous } \\
\text { validity (non-exclusive) }\end{array}$ & $\begin{array}{l}\text { His wife more or less knew about the } \\
\text { affair }\end{array}$ \\
\hline $\begin{array}{l}\text { E1: not X, } \\
\text { (but) Y }\end{array}$ & (B): confrontation & $\begin{array}{l}\text { Children aren't a luxury, they're a } \\
\text { necessity }\end{array}$ \\
\cline { 2 - 3 } & (D): correction & She herself didn't feel in the least \\
\hline
\end{tabular}




\begin{tabular}{|l|l|l|}
\hline & (substitution) & $\begin{array}{l}\text { sleepy. On the contrary, she felt wide } \\
\text { awake }\end{array}$ \\
\hline E2: X, not Y & $\begin{array}{l}\text { (D): } \\
\text { (emphasis) }\end{array}$ & $\begin{array}{l}\text { I wish to assist a love-affair-not to } \\
\text { hinder it }\end{array}$ \\
\hline $\begin{array}{l}\text { F: X rather } \\
\text { than Y }\end{array}$ & (E): comparison & $\begin{array}{l}\text { Her lips were dry, and hard rather } \\
\text { than soft }\end{array}$ \\
\hline $\begin{array}{l}\text { G: X turns } \\
\text { into Y }\end{array}$ & (F): mutation & $\begin{array}{l}\text { We want turn some our enemies into } \\
\text { friends }\end{array}$ \\
\hline $\begin{array}{l}\text { H: from X to } \\
\text { Y }\end{array}$ & (H): cumulative validity & $\begin{array}{l}\text { Near to it were placed a number of } \\
\text { suitcases ranged neatly in order from } \\
\text { large to small }\end{array}$ \\
\hline I1: X, Y & (A): cumulative validity & He half-smiled, half-sighed \\
\cline { 2 - 3 } (B): confrontation & He is in the light, I in the shade \\
\hline I2: X, Y & (G): reversal & $\begin{array}{l}\text { History had been made and unmade } \\
\text { at informal weekend }\end{array}$ \\
\hline
\end{tabular}

\subsubsection{Jones's categories}

Jones (2002) has conducted the most pioneering, rather the most comprehensive, corpus-based study of canonical antonyms in English. Using 3000 database sentences from 280-million words driven from the Independent newspaper, he has preselected 56 canonical antonyms and categorized them into eight (later nine) categories according to the syntactic frames in which they co-occur. The product is a dynamic typology of the discourse functions of such antonyms based on forms and functions of these frames (cf. Davies 2012:45). Being methodologically rigorous, Jones's typology has been extensively retrieved and replicated across a variety of datasets and languages as previously mentioned. Table 9 summarizes Jones's categorization, which has been serving as an analytic toolkit for later studies, most notably those conducted by his fellow members of the Comparative Lexical Relations Group. ${ }^{4}$

Table 9: A summary of Jones's (2002) typology of antonymy (adapted from Hassanein 2018:27)

\begin{tabular}{|l|l|l|}
\hline Category & Description & Example \\
\hline $\begin{array}{l}\text { Ancillary } \\
\text { Antonymy }\end{array}$ & $\begin{array}{l}\text { signals another antonymous } \\
\text { pair not usually seen } \\
\text { contrastively }\end{array}$ & $\begin{array}{l}\text { Form is temporary, class is } \\
\text { permanent }\end{array}$ \\
\hline $\begin{array}{l}\text { Comparative } \\
\text { Antonymy }\end{array}$ & $\begin{array}{l}\text { gauges one antonym against } \\
\text { another in a comparative } \\
\text { context }\end{array}$ & $\begin{array}{l}\text { Reward is more effective than } \\
\text { punishment }\end{array}$ \\
\hline $\begin{array}{l}\text { Co-ordinated } \\
\text { Antonymy }\end{array}$ & $\begin{array}{l}\text { joins two antonyms on a } \\
\text { scale either inclusively or } \\
\text { exhaustively }\end{array}$ & $\begin{array}{l}\text { Whitehall was yesterday unable } \\
\text { to confirm or deny other } \\
\text { simulated devolutions }\end{array}$ \\
\hline $\begin{array}{l}\text { Distinguished } \\
\text { Antonymy }\end{array}$ & $\begin{array}{l}\text { makes a metalinguistic } \\
\text { distinction between } \\
\text { antonyms }\end{array}$ & $\begin{array}{l}\text { One must distinguish between } \\
\text { hard and soft drugs. }\end{array}$ \\
\hline
\end{tabular}




\begin{tabular}{|l|l|l|}
\hline $\begin{array}{l}\text { Extreme } \\
\text { Antonymy }\end{array}$ & $\begin{array}{l}\text { draws contrast between } \\
\text { extremes of a scale and } \\
\text { space in between }\end{array}$ & $\begin{array}{l}\text { No-one can afford to go to law } \\
\text { except the very rich and the } \\
\text { very poor }\end{array}$ \\
\hline $\begin{array}{l}\text { Idiomatic } \\
\text { Antonymy }\end{array}$ & $\begin{array}{l}\text { pairs antonyms in a } \\
\text { proverbial or clichéd set } \\
\text { phrase }\end{array}$ & $\begin{array}{l}\text { The long and the short of it is } \\
\text { that height counts }\end{array}$ \\
\hline $\begin{array}{l}\text { Negated } \\
\text { Antonymy }\end{array}$ & $\begin{array}{l}\text { negates one antonym in } \\
\text { favor of another }\end{array}$ & $\begin{array}{l}\text { However, the citizen pays for } \\
\text { services to work well, not } \\
\text { badly }\end{array}$ \\
\hline $\begin{array}{l}\text { Transitional } \\
\text { Antonymy }\end{array}$ & $\begin{array}{l}\text { describes a change from one } \\
\text { state to another }\end{array}$ & $\begin{array}{l}\text { Her film career similarly has } \\
\text { lurched from success to failure }\end{array}$ \\
\hline
\end{tabular}

\subsubsection{Davies's categories}

Davies (2012, 2013) has swum against the common stream and approached antonymy afresh under a more general term that he prefers to call 'opposition'. His study proposes a provisional typology of the discourse functions of noncanonical oppositions based on the syntactic frames in which they co-occur. The typology draws heavily on Jones's corpus-based study of canonical antonyms in similar syntactic environments, but has substantially been revised and refined. These syntactic frames trigger non-canonical oppositions between items which are not considered opposites in neutral contexts but interact in context to contribute binary representations of people and things. Table 10 summarizes Davies's typology with examples.

Table 10: An overview of Davies's $(2012,2013)$ typology of opposition (adapted from Hassanein 2018:28)

\begin{tabular}{|l|l|l|}
\hline Category & Description & Example \\
\hline $\begin{array}{l}\text { Negated } \\
\text { Opposition }\end{array}$ & $\begin{array}{l}\text { expressing preference for } \\
\text { one state over another }\end{array}$ & $\begin{array}{l}\text { We are not a colony; we are an } \\
\text { equal and valued part of this } \\
\text { nation }\end{array}$ \\
\hline $\begin{array}{l}\text { Transitional } \\
\text { Opposition }\end{array}$ & $\begin{array}{l}\text { transforming from one state } \\
\text { to a (non)canonical opposite }\end{array}$ & $\begin{array}{l}\text { British marchers have spurned } \\
\text { isolation for solidarity, and fear } \\
\text { for fury }\end{array}$ \\
\hline $\begin{array}{l}\text { Comparative } \\
\text { Opposition }\end{array}$ & $\begin{array}{l}\text { measuring X against Y } \\
\text { either directly or indirectly }\end{array}$ & $\begin{array}{l}\text { But more important than the fate } \\
\text { of Labour is the fate of } \\
\text { mankind }\end{array}$ \\
\hline $\begin{array}{l}\text { Replacive } \\
\text { Opposition }\end{array}$ & $\begin{array}{l}\text { expressing an alternative } \\
\text { option to that which it is } \\
\text { opposed }\end{array}$ & $\begin{array}{l}\text { He predicted his plans would be } \\
\text { published "in weeks rather than } \\
\text { months" }\end{array}$ \\
\hline $\begin{array}{l}\text { Concessive } \\
\text { Opposition }\end{array}$ & $\begin{array}{l}\text { creating contrast between } \\
\text { two conjoined phrases or } \\
\text { clauses }\end{array}$ & $\begin{array}{l}\text { There was plenty of passion but } \\
\text { the marchers remained good- } \\
\text { natured }\end{array}$ \\
\hline $\begin{array}{l}\text { Explicit } \\
\text { Opposition }\end{array}$ & $\begin{array}{l}\text { making an explicit } \\
\text { metalinguistic difference }\end{array}$ & $\begin{array}{l}\text { The professionally-produced } \\
\text { placards . . contrasted with }\end{array}$ \\
\hline
\end{tabular}




\begin{tabular}{|l|l|l|}
\hline & between X and Y & cobbled-together banners \\
\hline Parallelism & $\begin{array}{l}\text { repeating structures within } \\
\text { which specific opposed } \\
\text { items are foregrounded }\end{array}$ & $\begin{array}{l}\text { It wasn't a march; it was an } \\
\text { invasion }\end{array}$ \\
\hline $\begin{array}{l}\text { Binarized } \\
\text { Option }\end{array}$ & $\begin{array}{l}\text { creating a choice between } \\
\text { two mutually exclusive } \\
\text { options }\end{array}$ & $\begin{array}{l}\text { Either you are with us or you are } \\
\text { with the terrorists }\end{array}$ \\
\hline
\end{tabular}

What is insightful about Davies's seminal typology of noncanonical oppositions in discourse is that it opens doors for the ideological repercussions of opposition in discourse and places contrast, canonical (antonymy) and noncanonical (opposition), on an infinite cline from conventional canonicity to unconventional non-canonicity.

\section{Conclusions}

This overview article has sought to diachronically compare the development of Arabic tiba: $q$ and English antonymy over the time, tracking and reviewing the theoretical and practical advancements of both phenomena in a comparative context.

By definition, both phenomena, despite their belongingness to incommensurable languages from different families, share several aspects in theory and practice. They prove to be rather difficult to define and specify operationally. Working definitions of either phenomenon seem to overlap and denote a multiplicity of semantically versatile concepts, underpinning a case of polyonymy in reference to both notions. Both phenomena are better suited to exemplification than definition and to illustration than description (cf. Jones 2002:10). Thus, finding a consistent definition of either term is more problematic than one expects, which may explain why either phenomenon is dichotomously approached, i.e., canonically vs. non-canonically, lexically vs. semantically, literally vs. non-literally, and textually vs. contextually. Either approach cannot dispense with the other and any adequate definition of either notion must be synergic, i.e., acting cooperatively rather than competitively.

As for classification, both phenomena have been typologically dissected by theorists, notably rhetoricians, tropologists, semanticists, and linguists. Each phenomenon has been classified according to the classifiers' theoretical insights and practices. The traditional typologies of both phenomena in both languages have generally originated according to a form-based and context-free relation between opposites. Former studies have mainly drawn on opposites co-occurring in syntax-free environments in both languages (cf. Davies 2012:43). State-of-theart studies of opposition in either language have drastically shifted the linguistic foci upon oppositeness from syntax- and context-free perspectives to syntax- and context-dependent ones and from canonicity to non-canonicity. Antonymy, the canonical relation of oppositeness across languages, has been dramatically broadened in scope to comprise a variety of conventionally and nonconventionally oppositional configurations. These configurations feature oppositions between antonyms, contrasts, counterparts, incompatibles, analogs, and other related terms. 
Such oppositions accommodate almost all parts of speech: nouns, verbs, adjectives, adverbs and pronouns. Arabic differs considerably from English in terms of pronominal use, particularly antonymous demonstratives (proximal vs. distal). For an informative work on this special topic, see Alqarni (2020).

\section{Future extensions}

Traditional approaches to attiba:q in Arabic tropology and recent approaches to antonymy in English semantics open up new horizons onto the analysis of noncanonical oppositions in discourse across languages. In classical Arabic rhetoric, attiba:q is said to comprise 'canonical opposition' and 'non-canonical opposition'. Al-Qarta:janni: (died 1284 (2008:48)) mentions al-mahd and ghayr al-mahd as major categories, in which opposition features between conventional opposites and also between non-opposites. Al-Qazwi:ni: (died 1338 (2003:258)) contributes attiba:q shibh al-mahd 'semi-canonical opposition' and al-muqa:bala 'canonical and non-canonical opposition'. Attayyibi: (died 1342 (1977:197)) also broadens the range of antonymy by introducing al-muqa:bala as a term inclusive of (non-)canonical opposition. In classifying attiba:q, Al- ${ }^{\mathrm{A}}$ Alawi: (died 1346 (1914:378-386)) also appears to introduce al-muqa:bala when broaching ashshay? 'thing' bi-ma: yukha:lifuh min ghayr muda:da 'incompatibles' and ashshay? bi-ma: yuma:thiluh 'analogs'.

It is noteworthy that these traditional views in classical Arabic rhetoric are currently mirrored in contemporary English lexical semantics. In ancillary antonymy whereby an A-pair of antonyms co-occurs to signal a more significant B-pair, Jones (2002:47) introduces canonicity (innate opposition), semi-canonicity (less innate opposition) and non-canonicity (no innate opposition). In broaching her principle 'Relation by Contrast-Lexical Contrast (RC-LC), Murphy (2003:43) explains that unrelated words can be conceptually related and the contrast relation (i.e., al-muqa:bala or 'opposition') can be derived between any pairing in discourse ranging from canonical, less canonical and (contextually motivated) non-canonical pairs. A by-product of these insights is the creation of possibilities for introducing non-canonical examples of opposition that have their inception in Davies's $(2012,2013)$ seminal investigations of non-canonical oppositions and their ideological repercussions. The present study recommends further extensive research on situationally or contextually induced non-canonical oppositions.

\section{Endnotes}

${ }^{1}$ This study has been supported by the Deanship of Scientific Research at Prince Sattam Bin Abdulaziz University, Alkharj, Saudi Arabia.

${ }^{2}$ The same line of verse is featured twice in 19 and 20 based on the number of opposite pairs therein: four canonical pairs in the former and the same four plus a noncanonical pair (li:/bi: 'for me/against me') in the latter.

${ }^{3}$ Hurford et al. (2007) call Lyons's (1977) cyclical and serial sets 'multiple incompatibility' which logs a borderline collection of antonyms, including pairs such as summer/winter and spring/autumn.

${ }^{4}$ See http://www.f.waseda.jp/vicky/complexica/.

${ }^{5}$ Then another category, 'interrogative antonymy', which signals co-occurrence 
of a contrastive pair in an interrogative, usually disjunctive, context (X or $\mathrm{Y}$ ?) to request information or show preference, has emerged. It has been introduced by Jones and Murphy (2005) in their investigations of spoken English and is polyonymically referred to as 'disjunctive antonymy' (cf. Muehleisen and Isono 2009: 2197) and 'binarized option' (cf. Davies 2012: 69). One example is 'Is she a good mommy or a bad mommy?'

Hamada Hassanein

Department of English

College of Science and Humanities,

Prince Sattam bin Abdulaziz University, Alkharj

Email: h.hassanein@psau.edu.sa|kheshin@mans.edu.eg

\section{References}

'Abd Al- ${ }^{\mathbf{c} A z i}$ :z Al-Jurja:ni:, 'Ali:. (1966). Al-Wasa:ta bayna Al-Mutanabbi: waKhusu:mih. Cairo: Matba ${ }^{\mathrm{c}}$ at ${ }^{\mathrm{C}} \mathrm{I}: \mathrm{sa}$.

Abdul-Raof, Hussein. (2006). Arabic Rhetoric: A Pragmatic Analysis. London and New York: Routledge.

Al-'Alawi:, Yahya:. (1914). Attira:z Al-Mutadammin li:-PAsra:r Al-Bala:gha wa${ }^{c} U: l u: m$ Haqa:Piq Al-PI'ja:z (2nd sec.). Cairo: Matba 'at Al-Muqtataf.

Al-PA:midi:, Abu: Al-Qa:sim. (1992). Al-Muwa:zana bayna Shicr Abi: Tamma:m wa-l-Buhturi: (4th ed.). Cairo: Da:r Al-Ma ${ }^{\mathrm{c}}$ a:rif.

Al- ${ }^{c}$ Askari, Abu: Hila:I. (1952). Kita:b Assina: ${ }^{c}$ atayn: Al-Kita:ba wa-Shshicr. Nasr City: Da:r Al-'Ilm wa-Ththaqa:fa.

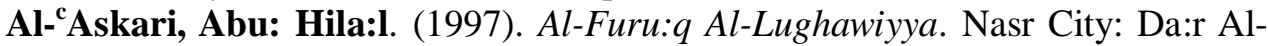
'Ilm wa-Ththaqa:fa.

Al-Baqilla:ni:, Abu: Bakr. (1972). I'ja:z Al-Qur?a:n (3rd ed.). Cairo: Da:r AlMa ${ }^{\mathrm{a}} \overline{\mathrm{a}} \mathrm{if}$.

AlHedayani, Rukayah. (2016). Antonymy in Modern Standard Arabic. Unpublished PhD Dissertation, University of Sussex.

Al-Jamma:s, Nicam. (2002). Attiba:q fi: al-qur?a:n al-kari:m: dira:sa bala:ghiyya. Unpublished MA Thesis, University of Mosul.

Al-Jurja:ni:, 'Abd Al-Qa:hir. (N.D.). Kita:b PAsra:r Al-Bala:gha. Jeddah: Da:r Al-Madani:.

Al-Khafa:ji:, 'Abd Alla:h. (1982). Sirr Al-Fasa: $\underline{h a}$ (1st ed.). Beirut: Da:r AlKutub Al-'Ilmiyya.

Al-Kharabsheh, Aladdin. (2008). 'Translating autoantonymy in the Qur'an'. Across Languages and Cultures, 9 (1): 17-40.

Al-Madani:, Ibn Ma ${ }^{\mathbf{c}} \mathbf{\text { uu}}$ :m. (1969). PAnwa:r Al-Rabi: ${ }^{c}$ fi: PAnwa: ${ }^{c}$ Al-Badi: ${ }^{c}$ (1st ed., 2nd sec.). Karbala: Matba ${ }^{\mathrm{c}}$ at Annu ${ }^{\mathrm{c}} \mathrm{ma}: \mathrm{n}$. 
cAfi:fi:, Subhi:. (1998). Bala:ghat attiba:q wa-l-muqa:bala fi: al-hadi:th annabawi: ashshari:f fi: Assahishayn. Unpublished MA Thesis, Al-Azhar University.

Alqarni, Muteb. (2020). 'The morphosyntax of the demonstrative system in Classical Arabic: A distributed morphology account'. International Journal of Arabic-English Studies, 20 (1): 19-50.

Al-Qarta:janni:, Ha:zim. (2008). Minha:j Al-Bulagha:? wa-Sira:j al-PUdaba:?. Beirut: Da:r Al-Gharb Al-PIsla:mi:.

Al-Qayrawa:ni:, Ibn Rashi:q. (1943). Al- ${ }^{c} U m d a$ fi: Maha:sin Ashshic $r$ waPA:da:bih wa-Naqdih (1st part). Cairo: Da:r al-Ji:l.

Al-Qazwi:ni:, Al-Khatitb. (2003). Al-PI $\underline{d a} a \underline{h}$ fi: ${ }^{c} U l u: m$ Al-Balagha: Al-Maca:ni:, Al-Baya:n wa-l-Badi: ${ }^{c}$. Beirut: Da:r Al-Kutub Al- ${ }^{\mathrm{I}}$ Almiyya.

Assakka:ki:, Yu:suf. (1987). Mifta: $\underline{h}$ Al- ${ }^{c} U l u: m$ (2nd ed.). Beirut: Da:r Al-Kutub Al-'Ilmiyya.

Ashshaykh, 'cAbd Al-Wa:hid. (1999). Al-Badi: ${ }^{c}$ wa-Ttawa:zi: (1st ed.). Alexandria: Maktabat wa-Matba ${ }^{\mathrm{c}}$ at Al-PIsh ${ }^{\mathrm{c}} \mathrm{a}:^{\mathrm{c}}$ Al-Fanniyya.

Attabri:zi:, Al-Khatítb. (1994). Kita:b Al-Ka:fi: fi: Al- ${ }^{c}$ Aru:d wa-l-Qawa:fi: (3rd ed.). Cairo: Maktabat Al-Kha:nji:.

Attayyibi:, Sharaf Addi:n. (1977). Attibya:n fi: Al-Bayan. Edited by ${ }^{\mathrm{c}}$ Abd Assata:r Husayn Mabru:k Zammu:t. Unpublished PhD Thesis, Al-Azhar University.

Azzarkashi:, Badr Addi:n. (2006). Al-Burha:n fi: 'Ulu:m Al-Quria:n. Cairo: Da:r Al- $\underline{\text { Hadi:th. }}$

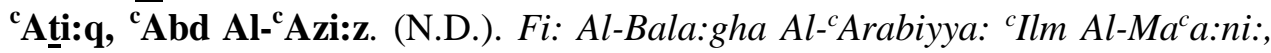
Al-Baya:n, Al-Badi: ${ }^{c}$. Beirut: Da:r Al-Nahda Al- ${ }^{c}$ Arabiyya.

Bin Malik, Badr Addi:n. (1989). Al-Misba:h fi: Al-Maca:ni:, Al-Baya:n, AlBadi: ${ }^{c}$. Cairo: Maktabat Al-PA:da:b.

Bussmann, Hadumod. (1996). Routledge Dictionary of Language and Linguistics. Trans. and ed. by Gregory P. Trauth and Kerstin Kazzazi. London and New York: Routledge.

Correia, Manuel. (2017). 'Aristotle's square of opposition'. South American Journal of Logic, 3 (1): 1-14.

Cruse, Alan. (1976). 'Three classes of antonym in English'. Lingua, 38: 281-292.

Cruse, Alan. (1986). Lexical Semantics. Cambridge: Cambridge University Press.

Cruse, Alan. (2000). Meaning in Language: An Introduction to Semantics and Pragmatics. Oxford: Oxford University Press.

Cruse, Alan. (2006). A Glossary of Semantics and Pragmatics. Edinburgh: Edinburgh University Press.

Crystal, David. (1985). A Dictionary of Linguistics and Phonetics (2nd ed.). New York: Basil Blackwell.

Crystal, David. (2008). A Dictionary of Linguistics and Phonetics (6th ed.). Oxford: Blackwell.

Davies, Matt. (2012). 'A new approach to oppositions in discourse: the role of syntactic frames in the triggering of noncanonical oppositions'. Journal of English Linguistics, 40 (1): 41-73. 
Davies, Matt. (2013). Oppositions and Ideology in News Discourse. London: Bloomsbury.

Fari:d, 'A:Pisha. (2000). Washy Arrabi: ${ }^{c}$ bi-PAlwa:n Al-Badi: ${ }^{c}$ fi: DQ $u$ ? AlPAsa:li:b Al- ${ }^{c}$ Arabiyya. Cairo: Da:r Quba:?.

Fellbaum, Christiane. (1995). 'Co-occurrence and antonymy'. International Journal of Lexicography, 8 (4): 281-303.

Finch, Geoffrey. (1998). How to Study Linguistics. Hampshire and New York: Palgrave Macmillan.

Fromkin, Victoria, Robert Rodman and Nina Hyams. (2003). An Introduction to Language (7th ed.). Massachusetts: Thomson Wadsworth.

Gheltofan, Daniela. (2013). 'Functional categories of antonymy in Romanian'. CICCRE, II: 328-341.

Gorgis, Dina T. and Huda F. Al-Halawachy. (2001). 'Antonymy and Related Terms'. ADAB AL-RAFIDAYN, 64: 25-58.

Griffiths, Patrick. (2006). An Introduction to English Semantics and Pragmatics. Edinburgh: Edinburgh University Press.

Hassanein, Hamada. (2013). The lexical semantics of antonymy in the qur?a:n: a linguistic study. Unpublished PhD Dissertation, Benha University.

Hassanein, Hamada. (2018). 'Discourse functions of opposition in Classical Arabic: the case in Hadith Genre'. Lingua, 201: 18-44.

Hsu, Chan-Chia. (2015). 'A syntagmatic analysis of antonym co-occurrences in Chinese: contrastive constructions and co-occurrence sequences'. Corpora, 10 (1): 47-82.

Hurford, James, Brendan Heasley and Michael Smith. (2007). Semantics: A Coursebook (2nd ed.). Cambridge: Cambridge University Press.

Husayn, 'Abd Al-Qa:dir. (1983). Fan Al-Badi:c (1st ed.). Cairo: Da:r Ashshuru:q.

Ibn Al-PAthi:r, Diya:? Addi:n. (N.D.). Al-Mathal Assa:Pir fi: PAdab Al-Ka:tib wa-Shsha: ${ }^{c}$ ir. Cairo: Da:r Nahdat Misr.

Ibn Al-Mu'taz, 'A Abd Alla:h. (1982). Kita:b Al-Badi:c. Introd. by Ignatius Kratchkovsky. Beirut: Da:r Al-Masi:ra.

Ibn Al-Qayyim, Shams Addi:n. (1327 H.). Kita:b Al-Fawa?id: Al-Mushawwiq Pila: 'Clu:m Al-Qur?a:n wa- ${ }^{c} I l m$ Al-Baya:n. (1st ed.). Cairo: Matba ${ }^{c} a t$ Assaca:da.

Ibn ManTHu:r, Jama:I Addi:n. (N.D.). Lisa:n Al-c Arab (2nd vol.) Beirut: Da:r Sa:dir.

Jackson, Howard. (1988). Words and their Meaning. London: Longman.

Jeffries, Leslie. (1998). Meaning in English: An Introduction to Language Study. Hampshire and London: Macmillan Press Ltd.

Jones, Steven. (2002). Antonymy: A Corpus-based Perspective. London and New York: Routledge.

Jones, Steven and Murphy, M. Lynne. (2005). 'Using corpora to investigate antonym acquisition'. International Journal of Corpus Linguistics, 10 (3): 401-422. 
Jones, Steven, M. Lynne Murphy, Carita Paradis and Caroline Willners. (2012). Antonyms in English: Construals, Constructions and Canonicity. Cambridge: Cambridge University Press.

Justeson, John and Slava Katz. (1991). 'Co-occurrences of antonymous adjectives and their contexts'. Computational Linguistics, 17 (1): 1-19.

Karaman, Burcu. (2008). 'On contronymy'. International Journal of Lexicography, 21 (2): 173-192.

Kostić, Nataša. (2011). 'Antonymous frameworks in Serbian written discourse: phrasal contexts of antonym co-occurrence in text'. Poznań Studies in Contemporary Linguistics, 47 (3): 509-537.

Lehrer, Adrienne and Keith Lehrer. (1982). 'Antonymy'. Linguistics and Philosophy, 5: 483-501.

Lobanova, Anna, Tom van der Kleij and Jennifer Spenader. (2010). 'Defining antonymy: a corpus-based study of opposites by lexico-syntactic patterns'. International Journal of Lexicography, 23 (1): 19-53.

Lyons, John. (1977). Semantics. Cambridge: Cambridge University Press.

Lyons, John. (1995). Linguistic Semantics: An Introduction. Cambridge: Cambridge University Press.

Mettinger, Arthur. (1994). Aspects of Semantic Opposition in English. Oxford: Oxford University Press.

Muehleisen, Victoria. (1997). Antonymy and semantic range in English. Unpublished PhD Dissertation, Northwestern University.

Muehleisen, Victoria and Maho Isono. (2009). 'Antonymous adjectives in Japanese discourse'. Journal of Pragmatics, 1 (11): 2185-2203.

Murphy, Gregory and Jane Andrew. (1993). 'The conceptual basis of antonymy and synonymy in adjectives'. Journal of Memory and Language, 32: 301319.

Murphy, Lynne. (1994). In opposition to an organised lexicon: pragmatic principles and lexical semantic relations. Unpublished $\mathrm{PhD}$ Dissertation, University of Illinois.

Murphy, Lynne. (2003). Semantic Relations and the Lexicon: Antonymy, Synonymy, and Other Paradigms. Cambridge: Cambridge University Press.

Murphy, Lynne. Carita Paradis, Caroline Willners and Steven Jones. (2009). 'Discourse functions of antonymy: a cross-linguistic investigation of Swedish and English'. Journal of Pragmatics, 41 (11): 2159-2184.

Palmer, Frank. (1981). Semantics (2nd ed.). Cambridge: Cambridge University Press.

Quda:ma ibn Ja far, Abu: Al-Faraj. (N.D.) Naqd Ashshic $r$. Beirut: Da:r AlKutub Al-'Ilmiyya.

Sibawayh, Abu: Bishr. (1988). Al-Kita:b (3rd ed.). Cairo: Maktabat Al-Kha:nji:.

Storjohann, Petra (ed.). (2010). Lexical-semantic Relations: Theoretical and Practical Perspectives. Amsterdam: John Benjamins Publishing Company.

Tha ${ }^{c}$ lab, Abu: Al- ${ }^{\mathbf{c}}$ Abba:s. (1995). Qawa: ${ }^{c} i d$ Ashshic $r$ (2nd ed.). Cairo: Maktabat Al-Kha:nji:. 
Appendix 1: Transliteration symbols for Arabic vowels and consonants

\begin{tabular}{|c|c|c|c|}
\hline Arabic Letter & English Symbol & Arabic Example & $\begin{array}{l}\text { English } \\
\text { Equivalent }\end{array}$ \\
\hline$\&$ & $?$ & Pamal & hope \\
\hline ب & $\mathrm{b}$ & ba:b & door \\
\hline$ت$ & $\mathrm{t}$ & tibn & chaff \\
\hline$\dot{H}$ & th & thaclab & fox \\
\hline ج & $\mathrm{j}$ & jamal & camel \\
\hline$\tau$ & $\underline{\mathrm{h}}$ & hubb & love \\
\hline$\dot{\tau}$ & $\mathrm{kh}$ & khubz & bread \\
\hline د & $\mathrm{d}$ & dubb & bear \\
\hline j & $\mathrm{dh}$ & dhahab & gold \\
\hline J & $\mathrm{r}$ & $\mathrm{rabb}$ & Lord \\
\hline j & $\mathrm{Z}$ & zayt & oil \\
\hline س س & $\mathrm{s}$ & sabt & Saturday \\
\hline ش & sh & shams & sun \\
\hline ص ص & $\underline{\mathrm{S}}$ & sayf & summer \\
\hline ض ض & $\underline{\mathrm{d}}$ & dayf & guest \\
\hline b & $\underline{\mathrm{t}}$ & ti:n & mud \\
\hline ظ & $\mathrm{TH}$ & THuhr & noon \\
\hline$\varepsilon$ & c & cabd & slave \\
\hline$\dot{\varepsilon}$ & gh & gharb & west \\
\hline ف & $\mathrm{f}$ & famm & mouth \\
\hline ق & $\mathrm{q}$ & qalam & pencil \\
\hline 5 & $\mathrm{k}$ & kita:b & book \\
\hline J & 1 & layl & night \\
\hline r & $\mathrm{m}$ & makr & guile \\
\hline ن & $\mathrm{n}$ & nawm & sleep \\
\hline هـ & $\mathrm{h}$ & hudhud & hoopoe \\
\hline وَ & $\mathrm{W}$ & ward & rose \\
\hline ي & $\mathrm{y}$ & yawm & day \\
\hline (فتحة) & $\mathrm{a}$ & kataba & he wrote \\
\hline (ضمة) & $\mathrm{u}$ & kutub & books \\
\hline (كسرة) & $\mathrm{i}$ & $\sin n$ & tooth \\
\hline مد طويل ا/ى & $\mathrm{a}:$ & ka:tib & writer \\
\hline ضمة طويلة و & $\mathrm{u}:$ & fu:1 & beans \\
\hline كسرة طويلة ي & i: & fi:l & elephant \\
\hline \multirow{2}{*}{$\begin{array}{l}\text { Diphthongs } \\
\text { (أصوات علة مركبة) }\end{array}$} & aw & mawt & death \\
\hline & ay & bayt & house \\
\hline
\end{tabular}

Source: Retrieved and adapted from http://www.ijaes.net/Author/Help and accessed on 07/03/2020. 